\title{
DROUGHT STRESS TOLERANCE IN TRANSGENIC WHEAT CONFERRED BY EXPRESSION OF A DEHYDRATION- RESPONSIVE ELEMENT-BINDING 1A GENE
}

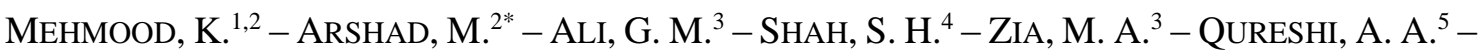 \\ QURESHI, R. ${ }^{2}$ \\ ${ }^{\text {I} D e p a r t m e n t ~ o f ~ B i o l o g y / B o t a n y, ~ P i r ~ M e h r ~ A l i ~ S h a h ~ A r i d ~ A g r i c u l t u r e ~ U n i v e r s i t y, ~ R a w a l p i n d i, ~}$ \\ Attock Sub-Campus, Pakistan \\ ${ }^{2}$ Department of Botany, Pir Mehr Ali Shah Arid Agriculture University, Rawalpindi, Pakistan \\ ${ }^{3}$ National Institute for Genomics \& Advanced Biotechnology (NIGAB), National Agricultural \\ Research Centre (NARC), Islamabad, Pakistan \\ ${ }^{4}$ Department of Agricultural Sciences, Allama Iqbal Open University, Islamabad, Pakistan \\ ${ }^{5}$ Department of Horticulture, Pir Mehr Ali Shah Arid Agriculture University, Rawalpindi, \\ Pakistan \\ *Corresponding author \\ e-mail: arshad2uaar@yahoo.com \\ (Received $1^{\text {st }}$ Apr 2019; accepted $31^{\text {st }}$ Oct 2019)
}

\begin{abstract}
Drought stress hinders root and shoot growth, leaf area, biomass accumulation, plant fresh and dry weight signifying the severe losses of plant growth and development. During drought stress, different genes are activated that increase the drought tolerance efficiency of plants. In this study, DREBIA gene was transformed in wheat cv. Lasani-08 to improve drought tolerance efficiency after optimizing in planta Agrobacterium mediated transformation protocol. The results reveal that $3.0 \mathrm{mg} / 1 \mathrm{2}$, 4-D and $6 \mathrm{~h}$ soaking period were found to be the best combination for in planta transformation. The inoculation of seeds with Agrobacterium suspension before germination of apical meristem was proved to be the best time for obtaining more transformation efficiency (6.38\%) as compared to seeds inoculation after germination of apical meristem. Molecular analyses of transgenic plants through PCR, Southern blotting and RT-PCR confirmed the presence, number of copies and expression profile of transgene in $T_{1}$ generation. The drought tolerance efficiency was assessed in $\mathrm{T}_{2}$ transgenic plants on the basis of agronomical and biochemical analyses. These detailed analyses reveal that DREB1A gene has fostering effect on the expression of a large number of genes by means of enhanced germination frequency, germination rate index, shoot, root and coleoptiles lengths, relative water contents, proline contents and total chlorophyll contents of transgenic plants relative to control plants. In summary, our results propose that DREB1A is involved in improving drought stress tolerance of transgenic wheat by sustaining growth and yield of plants.
\end{abstract}

Keywords: drought stress, DREB1A, in planta transformation, proline contents, relative water contents, transgenic wheat, total chlorophyll contents

\section{Introduction}

Wheat (Triticum aestivum L.) is an important cereal crop and it plays a significant role in food security of the world. It is a major crop of Pakistan (Ishaq and Memon, 2016; Mehmood et al., 2016; Abbas et al., 2017). The contribution of wheat to GDP is $3.4 \%$ and its share in agriculture value addition is $13.8 \%$ (Adeel et al., 2017). Pakistan has to produce extra food grains to meet the dietary needs of the increasing population which is currently over 191.71 million (Pakistan Economic Survey, 2014-15). Overall 
dietary needs of the population have reached to twenty million tons wheat (Anjum et al., 2016). However, its productivity is affected by many environmental stresses due to sudden climatic changes and scarcity of water (Alghabari et al., 2015). Due to limitation of water resources, wheat cultivation area has been exposed to water shortage. Due to climatic changes and continuous droughts in summer, the yield losses have been more intensified. Severe yield losses can occur by drought stress because it can happen at any stage of development in wheat especially in arid and semi-arid areas (Farooq et al., 2011). Drought stress obstructs root growth, shoot growth, leaf area, biomass accumulation, plant fresh and dry weight signifying the severe losses of plant development (Xue et al., 2003; Jan et al., 2017). The degree of drought sensitivity is dependent on developmental phase of wheat plants because some developmental stage can cope with the drought, while others are highly sensitive to drought. For example, if wheat is vulnerable to drought stress before anthesis stage, then reduction in plant height, number of ears and leaf area will occur (Hassan et al., 1987). While the number of kernels per ear and weight of kernels of wheat is reduced if the drought stress occurs at lateral stages of development (Sieling et al., 1994). Soil moisture stress at heading stage caused reduction in shoot growth, while no drought effect was evident on root growth (Saidi et al., 2008). Similarly, 37\% yield reduction was recorded by shortage of water at booting to maturity stage, while this loss was increased to $44 \%$, when drought stress befell at heading to maturity stage (Prasad et al., 2011).

Plants have adopted many mechanisms to tolerate the effects of drought such as metabolic accumulation of organic solutes including proline, glycine betaine, sugars etc. (Zhu, 2001) wax accumulation (Chen et al., 2003) production of antioxidant enzymes (Mowla et al., 2002), abscisic acid accumulation (Marcotte et al., 1989) and through transcription factors (Jain et al., 2001). During drought stress, different genes are activated and increase the drought tolerance of plants. These include $B A D H, W X P 1$ and DREB1A (Zhang et al., 2005; Pellegrineschi et al., 2004). Researchers are trying to cope with drought problem using Agrobacterium mediated genetic transformation (Cheng et al., 1997; He et al., 2010). In this phenomenon, T-DNA region of the Ti-plasmid is excised, transformed into the host plant tissue and integrated into the genome of the plant (Ali et al., 2016). Agrobacterium mediated genetic transformation depends upon different factors affecting the rate of transformation (Amoah et al., 2001; Yenchon and Te-chato, 2012; Wu et al., 2003).

Genetic engineering approach is fast and precise means (Cushman and Bohnert, 2000) of genetic improvement of crops transferring only desirable genes into crop of interest (Jones, 2005). DREB1A gene enhanced the drought tolerance ability of transgenic plants triggering the expression of twelve $(C B F 3 / D R E B 1 A)$ target genes in non-stress condition, while 27 extra genes were stimulated in water stress conditions without involving growth retardation (Oh et al., 2005). Target genes of CBF3/DREB1A includes RNA binding proteins, transcription factors, KIN (cold inducible) proteins, Phospholipase C, Sugars transport proteins, Osmoprotectant biosynthesis proteins, Carbohydrate metabolism related proteins, Late embryogenesis abundant (LEA) proteins and the Proteinase inhibitors (Seki et al., 2001).

Gene transformation of wheat is still comparatively difficult as compared to other cereals due to relatively longer genome and being tissue culture recalcitrant crop. So, there is strong need to improve and select the proper methodology of genetic transformation. In planta Agrobacterium mediated transformation is a cheap and fast method to develop transgenic plants. It was previously used for the development of 
transgenic maize (Brunecky et al., 2011), tomato (Shah et al., 2015; Ali et al., 2018), rice (Andrieu et al., 2012), tobacco (Brunecky et al., 2011) and wheat (Borisjuk et al., 2019; Khan et al., 2019).

Keeping in view the above facts, the present study was planned to optimize the in planta transformation protocol for transformation of DREBIA gene through Agrobacterium strain EHA101 in wheat cultivar Lasani-08. During this study, concentration of 2, 4-D and soaking time of seeds were optimized. Comparison was made between two procedures of seeds inoculation i.e. inoculation before germination of seeds and inoculation after germination of seeds. The $\mathrm{T}_{2}$ transgenic plants were scrutinized on the basis of agronomical and biochemical characteristics.

\section{Materials and methods}

\section{Experimental sites and source of explants}

During our previous research study (Khalid et al., 2013), we confirmed that among six wheat cultivars namely Lasani-08, Inqalab 91, Tatara, Chakwal 97, GA-02 and Khyber obtained from Crop Science Institute (CSI), NARC Islamabad, one cultivar Lasani-08 was found to be the best for regeneration. Therefore, in this study we used cv. Lasani-08 and optimized factors affecting in planta transformation and then screening of transgenic plants was done on the basis of agronomical as well as biochemical characteristics. Optimization of in planta transformation protocol as well as transgenic wheat plants carried out in NIGAB, NARC, Islamabad, Pakistan, while screening of drought tolerance of transgenic line was done at Plant Physiology Lab, PMAS, Arid Agriculture University, Rawalpindi, Pakistan.

\section{Agrobacterium-mediated in planta transformation}

The experimental procedure of in planta transformation has been shown in Figure 1. Agrobacterium strain EHA101 carrying binary plasmid PCAMBIA containing DREB1A gene under $35 \mathrm{~S}$ promoter with $h p t$ (plant selectable marker gene) and kanamycin resistance gene (bacterial selectable marker gene) was used in this study (Fig. 2a). Seeds of wheat cv. Lasani-08 were washed with tap water to remove dust and surface sterilization was done with $70 \%$ ethanol for $30 \mathrm{~s}, 60 \%$ Clorox for $15 \mathrm{~min}$ and then washed with autoclaved distilled water 3-5 times to remove the Clorox from the surface of seeds. Sterilized seeds were placed on filter paper and soaked in distilled water supplemented with different concentration of 2, 4-D (2.0, 3.0 and $4.0 \mathrm{mg} / \mathrm{l})$ for 3, 6 and $9 \mathrm{~h}$ to get the suitable combination of soaking time and 2, 4-D for maximum transformation efficiency. On the other hands, in case of inoculation after germination, seeds were soaked in distilled water devoid of 2, 4-D until emergence of coleoptiles. Subsequently, seeds were peeled off with the help of forceps at the top of embryo to expose the embryonic apical meristem. O.D of overnight bacterial culture was maintained at $\mathrm{O}_{\mathrm{D}} \mathrm{D}_{600 \mathrm{~nm}}=0.8-1.0$ by photonanometer for co-infection. Embryo tip was cut with sharp blade, injured with acupuncture pin No.35 and a drop of Agrobacterium suspension was inserted. Then these seeds along with embryonic apical meristem were dipped in inoculation medium (Agrobacterium suspension containing $3.0 \mathrm{mg} / \mathrm{l}$ 2, 4-D and $300 \mu \mathrm{M}$ acetosyringone) for $40 \mathrm{~min}$. The culture was placed for $48 \mathrm{~h}$ in dark at $28{ }^{\circ} \mathrm{C}$ in growth chamber for co-cultivation. The Agrobacterium attached with seeds during co-cultivation were eliminated by washing with autoclaved distilled water then 
with MS liquid supplemented with $500 \mathrm{mg} / \mathrm{l}$ cefotaxime sodium. Sterilized seedlings were transferred in chiller at $5{ }^{\circ} \mathrm{C}$ for further development. Pre-selection media (MS liquid supplemented with $3.0 \mathrm{mg} / \mathrm{l} \mathrm{BAP,} 500 \mathrm{mg} / \mathrm{l}$ cefotaxime sodium) was used for first 3-5 d. Then culture was transferred to selection media (MS liquid, $250 \mathrm{mg} / \mathrm{l}$ cefotaxime and $50 \mathrm{mg} / \mathrm{l}$ hygromycin). These seedlings were vernalized for further 2-3 weeks and hygromycin selected seedlings were transferred to glass house under controlled conditions for further growth and development.

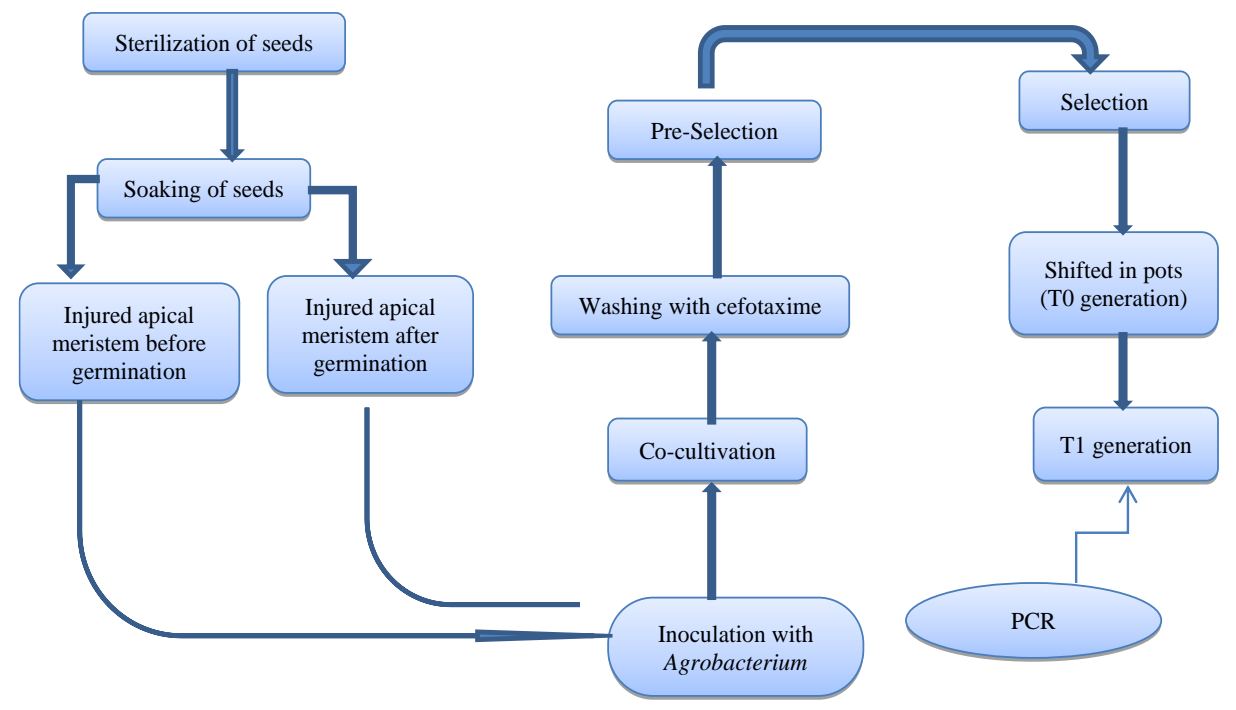

Figure 1. Flow diagram showing the development of wheat transgenic plants via in planta method of Agrobacterium-mediated transformation

\section{Confirmation of transgenic plants}

The 3-weeks old hygromycin resistant seedlings ( $\mathrm{T}_{0}$ generation) were shifted to glass house till maturity. The transgenic seeds of $T_{0}$ generation were further sown to get $T_{1}$ generation. When plants of $T_{1}$ generation reached up to 2-3 leaf stage, genomics DNA was isolated from fresh leaves by CTAB method (Murray and Thompson, 1980) and then PCR was performed using DREB1A gene specific primers; F 5'TGAACTCATTTTCTGCTTT-3' and R 5'-TAATAACTCCATAACGATA-3'. The product of PCR was run on $1 \%$ gel electrophoresis for $30 \mathrm{~min}$ at $100 \mathrm{~V}$ current and visualized by gel documentation system (Alpha imager HP) under UV light. The $5 \mu$ of each PCR product was loaded in gel with the help of $2.0 \mu \mathrm{l}$ bromophenol blue for each sample as loading dye. $1 \mathrm{~kb}$ ladder was used to compare size of required band (649 bp).

\section{Southern blotting}

The copy number of inserted gene in transgenic plants was determined through southern blotting. For probe preparation, plasmid DNA was isolated and amplified by PCR using DREBIA primers. About $50 \mu \mathrm{l}$ of PCR product of plasmid DNA was run on $1.5 \%$ gel electrophoresis applying $50 \mathrm{~V}$ voltage, $100 \mathrm{~A}$ current and $50 \mathrm{~W}$ power for $30 \mathrm{~min}$. The required band was visualized under UV light in gel documentation system and cut the gel around the band and transferred the band along with gel in Eppendorf tube. Binding buffer of $600 \mu \mathrm{l}$ was mixed, incubated for $10 \mathrm{~min}$ at $56^{\circ} \mathrm{C}$ with continuous shaking at the rate of $500 \mathrm{rpm}$ in incubator. After melting, gel was shifted 
into column and centrifugation was done at $14000 \mathrm{rpm}$ for $1 \mathrm{~min}$. Filtrate was discarded and pellet was washed with $700 \mu l$ washing buffer having ethanol through centrifugation at $14000 \mathrm{rpm}$ for $1 \mathrm{~min}$ and then filtrate was discarded. The $50 \mu 1$ elusion buffer was added at mid of membrane and incubated for $1 \mathrm{~min}$ in centrifuge machine and then started centrifugation at the rate of $14000 \mathrm{rpm}$ for $1 \mathrm{~min}$. The pure DNA was eluted and stored at $-80{ }^{\circ} \mathrm{C}$. DNA $(10 \mu \mathrm{g})$ of three transgenic plants $(\mathrm{K} 1, \mathrm{~K} 2, \mathrm{~K} 3)$ of $\mathrm{T}_{1}$ generation obtained from in planta transformation was digested with HindIII endonuclease. Then samples were run on $0.8 \%$ agarose gel. Subsequently, it was blotted on a nylon membrane. Non-Radioactively labeled (Fermentas Biotin DecaLabel DNA labeling kit) $649 \mathrm{bp}$ PCR amplified fragment plasmid DNA was used as a probe.

\section{RNA isolation and cDNA synthesis}

Leaf sample $(80 \mathrm{mg})$ was homogenized with the help of $1 \mathrm{ml}$ Tri reagent, and then this homogenized mixture was placed at room temperature for $5 \mathrm{~min}$ in Eppendorf tubes. $2 \mu \mathrm{l}$ of chloroform was added in this homogenized mixture and vigorously shaking was done for $15 \mathrm{~s}$. The homogenate was placed at room temperature for 2-15 min and then centrifugation was done at $12000 \mathrm{rpm}$ for $15 \mathrm{~min}$. After centrifugation, a colorless aqueous phase (having RNA) was appeared on the top of Eppendorf tube. This colorless aqueous phase was taken into new Eppendorf tube and $500 \mu 1$ isopropanol was added into each sample and stored for 5-10 $\mathrm{min}$ at room temperature. Again, centrifugation was done for $8 \mathrm{~min}$ at $12000 \mathrm{rpm}$. Supernatant was poured out and $70 \%$ ethanol ( $1 \mathrm{ml}$ for each sample) was used for washing RNA pellet, vertexed following centrifuge at $7500 \mathrm{rpm}$ for $5 \mathrm{~min}$. Ethanol discarded and pellet remained in Eppendorf which was air-dried for 3-5 min. RNAase free water was used to dissolve RNA pellet. This dissolved form of RNA incubated for 10-15 min at 55-60 ${ }^{\circ} \mathrm{C}$ temperature and then stored at $-80^{\circ} \mathrm{C}$ for further used. For cDNA synthesis, PCR profile was set as $65{ }^{\circ} \mathrm{C}$ for $5 \mathrm{~min}, 42{ }^{\circ} \mathrm{C}$ for $80 \mathrm{~min}$ and $72{ }^{\circ} \mathrm{C}$ for $10 \mathrm{~min} .20 \mu 1$ reaction volumes were used for each sample. Conventional PCR was carried out in two steps. In step one, PCR tubes were placed in PCR machine for 5 min at $65^{\circ} \mathrm{C}$. Each PCR tube contained RNA $(4 \mu 1)$, oligodT $(1 \mu \mathrm{l})$ and water $(9.5 \mu \mathrm{l})$. After $5 \mathrm{~min}$, they were chilled in ice for 2-3 min. In step 2 , for each sample, a master mixture containing RT buffer $(4 \mu 1)$, dNTPs $(1 \mu l)$ and RT $(0.5 \mu \mathrm{l})$ was prepared before starting first step PCR. This master mixture $(5.5 \mu \mathrm{l})$ was added into chilled PCR tubes getting total volume of $20 \mu 1$ in each PCR tube. Then, these PCR tubes were immediately placed in PCR machine at $42{ }^{\circ} \mathrm{C}$ for 80 min and $72{ }^{\circ} \mathrm{C}$ for $10 \mathrm{~min}$ (PCR profile was already set). After completion of cDNA synthesis, samples were stored at $-20{ }^{\circ} \mathrm{C}$ for further use in RT-PCR.

\section{RT-PCR analysis}

In order to check the expression of desired gene, RT-PCR analysis was performed. For it, a reaction volume $(20 \mu \mathrm{l})$ was used in each PCR tube. This reaction volume was made by mixing cDNA $(2 \mu \mathrm{l})$ with master mixture $(18 \mu \mathrm{l})$. For master mixture, $10.5 \mu \mathrm{l}$ water, forward $(1 \mu \mathrm{l})$ and reverse $(1 \mu \mathrm{l})$ primers, $2.4 \mu \mathrm{l} \mathrm{MgCl}_{2}, 0.4 \mu \mathrm{l}$ dNTPs, $0.3 \mu \mathrm{l}$ Taq Polymerase and $2 \mu \mathrm{l}$ Taq DNA buffer were mixed. PCR profile was set as: initial denaturation temperature $94{ }^{\circ} \mathrm{C}$ for $5 \mathrm{~min}$ for 1 cycle; for 35 cycles temperature profile was set as denaturation at $94{ }^{\circ} \mathrm{C}$ for $1 \mathrm{~min}$, annealing at $50{ }^{\circ} \mathrm{C}$ for $1 \mathrm{~min}$ and extension at $72{ }^{\circ} \mathrm{C}$ for $1 \mathrm{~min}$. At the end of one cycle, final extension temperature was set at $72{ }^{\circ} \mathrm{C}$ for $10 \mathrm{~min}$. 


\section{Evaluation of drought tolerance of transgenic plants on the basis of agronomical characteristics}

The transgenic plants were scrutinized for their drought tolerance at three stages. At first stage, Polyethylene Glycol (PEG) solution was applied on petri plates to induce artificial drought stress $(-2,-4,-6$ and -8 bars osmotic stress) in laboratory. The stock solution of PEG $8000(25 \% \mathrm{w} / \mathrm{v})$ was prepared using autoclaved distilled water. Then dilution of different concentration was prepared starting from $6.0 \%, 8.0 \%$ up to $24.0 \%$. The osmotic potential was measured using osmometer (Osmomate 030) at Central Laboratory PMAS, Arid Agriculture University, Rawalpindi, Pakistan. The reading was taken in osmomol $/ \mathrm{kg}$ which were converted into $\mathrm{MPa}$ using formula $=\mathrm{CRT}$, here $\mathrm{C}=$ Osmolality in moles per $\mathrm{kg}, \mathrm{R}=.0083$ and $\mathrm{T}=25^{\circ} \mathrm{C}+273$. MPa value was converted into bars by multiplying -10 . A graph (standard curve) was plotted between PEG percentage and bar values. Four levels of PEG (-2, -4, -6 and -8 bar) osmotic stress were used to induce drought at germination stage of transgenic and non-transgenic (control) plants by sowing seeds on moist filter papers with different levels of PEG solution at $25^{\circ} \mathrm{C}$. The healthy seeds were sterilized with $60 \%$ Clorox for $15 \mathrm{~min}$ followed by four to five times washing with autoclaved distilled water. Subsequently, they were placed in petri plates having two filter papers wet with $5 \mathrm{ml}$ of different PEGsolution. Petri plates were kept in growth chamber at $25^{\circ} \mathrm{C}$ and data about germination of seeds was recorded daily for 8 days. At second stage, drought stress was induced withholding water to transgenic and control plants in pots under glass house conditions. At third stage, transgenic plants were screened out on the basis of drought tolerance efficiency relevant to crop yield.

Data about germination percentage were recorded after the interval of $24 \mathrm{~h}$ up to 8 days. The calculation was made using this formula:

$$
\text { Germination }(\%)=\frac{\text { Number of seeds germinated }}{\text { Total number of seeds used }} \times 100
$$

Germination rate index was determined using the formula described by Camargo and Vaughan (1973):

$$
\text { Germination rate index }=\frac{\text { Number of seeds germinated }}{\text { day }}
$$

The length of shoot, root and coleoptiles were measured in $\mathrm{cm}$ with the help of scale at the $8^{\text {th }}$ day of experiment.

\section{Evaluation of drought tolerance of transgenic plants on the basis of biochemical characteristics}

The drought was induced at vegetative stage of $\mathrm{T}_{2}$ transgenic and control plants withholding water for 8 days. Relative water contents (RWC) of transgenic and control plants were determined following method proposed by Barrs and Weatherley (1962). Fresh leaves were excised from plants, sealed within aluminum file and plastic bag and quickly transferred to lab. Fresh weight was taken immediately after arrival in Laboratory. Then, turgid weight was taken after soaking leaves into distilled water for $6 \mathrm{~h}$ at room temperature. Dry weight was taken after drying the samples at $70{ }^{\circ} \mathrm{C}$ in an oven. Finally, the calculation of RWC was made with the help of following formula: 


$$
\text { RWC }(\%)=\frac{\text { Fresh weight-Dryweight }}{\text { Turgid weight-Dryweight }} \times 100
$$

Proline contents (mg/g fresh weight) were determined following the method devised by Bates et al. (1973). Fresh leaf sample $(0.25 \mathrm{~g})$ was ground and homogenized with $5 \mathrm{ml}$ of $3 \%$ sulfosalicylic acid. Extract was poured into test tubes and allowed to set down the debris. Then, $2 \mathrm{ml}$ of supernatant was taken into another test tube mixed with $2 \mathrm{ml}$ ninhydrin reagent (ninhydrin $=1.25 \mathrm{~g}$, glacial acetic acid $=30 \mathrm{ml}$ and $6 \mathrm{M}$ phosphoric acid; $20 \mathrm{ml}$ ) and $2 \mathrm{ml}$ glacial acetic acid. Samples were boiled in water bath at $100{ }^{\circ} \mathrm{C}$ for $1 \mathrm{~h}$ and then reaction was immediately stopped in ice. After cooling, $4 \mathrm{ml}$ toluene was added into each sample and shaken vigorously for few seconds, and upper layer of toluene appeared after few seconds. Supernatant was collected into another set of test tubes. Absorbance of supernatant was taken by spectrophotometer using the wavelength of $520 \mathrm{~nm}$. Toluene was used as a blank.

$$
\text { Proline contents }\left(\frac{\mathrm{mg}}{\mathrm{g}} \mathrm{FW}\right)=\frac{(\text { Absorbance of sample }) \times(\mathrm{k} \text { value }) \times(\text { Dilution factor })}{\text { Weight of sample }} \times 100
$$

Here FW denotes fresh weight.

Total chlorophyll contents (mg/g fresh weight) were measured in Plant Physiology Lab, PMAS, Arid Agriculture University, Rawalpindi, Pakistan according to the method of Arnon (1949). Fresh leaves (5 g) were immersed in $10 \mathrm{ml}$ of $80 \%$ ethanol; tubes were capped and digested the samples at $80{ }^{\circ} \mathrm{C}$ for $10 \mathrm{~min}$ in water bath. Green extract immediately was cooled down in incubator (as a dark room) to give protection from light because it degrades the chlorophyll. Optical density was measured after $3 \mathrm{~h}$ for chlorophyll "b" and chlorophyll "a" at $663 \mathrm{~nm}$ and $645 \mathrm{~nm}$, respectively using spectrophotometer. Ethanol (80\%) was used as a blank.

$$
\begin{gathered}
\text { Total chlorophyll contents }\left(\frac{\mathrm{mg}}{\mathrm{g}} \mathrm{FW}\right)=\frac{(20.2 \times 0 \mathrm{OD} \text { at } 645 \mathrm{~nm})+(8.02 \times 0 \mathrm{D} \text { at } 663 \mathrm{~nm})}{\text { Weight of sample }} \times \mathrm{V} \\
\text { Chlorophyll a contents }\left(\frac{\mathrm{mg}}{\mathrm{g}} \mathrm{FW}\right)=\frac{(12.7 \times 0 \mathrm{D} \text { at } 663 \mathrm{~nm})-(2.69 \times 0 \mathrm{D} \text { at } 645 \mathrm{~nm})}{1000 \times \mathrm{Fresh} \text { shoot weight }(\mathrm{g})} \times \mathrm{V} \\
\text { Chlorophyll b contents }\left(\frac{\mathrm{mg}}{\mathrm{g}} \mathrm{FW}\right)=\frac{(22.7 \times 0 \mathrm{O} \text { at } 663 \mathrm{~nm})-(4.69 \times 0 \mathrm{D} \text { at } 645 \mathrm{~nm})}{1000 \times \text { Freshshoot weight }(\mathrm{g})} \times \mathrm{V}
\end{gathered}
$$

Here: $\mathrm{V}=$ Volume of extract $(\mathrm{ml}) ; \mathrm{OD}=$ Optical density; FW = Fresh weight.

\section{Drought tolerance efficiency (\%)}

Comparison between transgenic and control plants was done on the basis of drought tolerance efficiency. The transgenic and control plants of $\mathrm{T}_{2}$ generation were divided into two groups. Each group contained both transgenic and control plants. Drought stress was applied to one group withholding water, while $2^{\text {nd }}$ group plants were kept as a control with continuous irrigation. Drought tolerance efficiency (DTE) was calculated keeping the yield of both groups by following the equation of Fischer and Wood (1981):

$$
\text { Drought tolerance efficiency }(\%)=\frac{\text { Yield under stress condition }}{\text { Yieldunder non-stress condition }} \times 100
$$


After calculating drought tolerance efficiency, both values were compared and difference was calculated that how much drought tolerance ability of transgenic plants increased through transformation of DREB $1 A$ gene.

Improvement in wheat for drought tolerance $=($ DTE\% of transgenic plants $)-$ (DTE\% of control plants).

Improvement in transgenic plants regarding average spike length, grains per spike, 100-grain weight was measured in both conditions i.e. normal and stress conditions and compared with control plants.

\section{Statistical analysis}

Data were recorded in percentage and statistical analysis was carried out applying ANOVA with two factorial CRD using statistics 8.1. Three replications were used for each treatment. The significance of treatment means was further analyzed using LSD test.

\section{Results}

\section{Optimization of soaking time and 2, $4 \mathrm{D}$ for in planta transformation}

The effects of two treatments ( 3 and $9 \mathrm{~h}$ soaking time) were non-significantly different from one another, while $6 \mathrm{~h}$ soaking time was significantly different from these two treatments showing maximum hygromycin resistant plants $(18.31 \%$ on average basis) on selection media (Table 1). Similarly, no significant differences were found between 2.0 and $4.0 \mathrm{mg} / \mathrm{l}$ of 2, 4-D, while $3.0 \mathrm{mg} / \mathrm{l}$ 2, 4-D showed significant difference from the other two treatments giving $21.8 \%$ hygromycin resistant plants. Subsequently, soaking time $6 \mathrm{~h}$ and $3.0 \mathrm{mg} / \mathrm{l} 2$, 4-D yielded $25.12 \%$ plants survived on the selection media. Conclusively, seeds were soaked in distilled water containing $3.0 \mathrm{mg} / \mathrm{l} 2$, 4-D for $6 \mathrm{~h}$ to get maximum transformation efficiency of our desired gene (Table 1).

Table 1. Effect of various soaking times and 2, 4-D concentrations on transformation efficiency (\%)

\begin{tabular}{|c|c|c|c|c|}
\hline \multirow[t]{2}{*}{ Soaking time (h) } & \multicolumn{4}{|c|}{ Hygromycin resistant plants $(\%)$} \\
\hline & $2 \mathrm{mg} / \mathrm{l}(2,4-\mathrm{D})$ & $3 \mathrm{mg} / \mathrm{l}(2,4-D)$ & $4 \mathrm{mg} / \mathrm{l}(2,4-\mathrm{D})$ & Mean \\
\hline 3 & $10.53 \mathrm{e}$ & $20.42 \mathrm{~b}$ & $9.23 \mathrm{e}$ & $13.39 \mathrm{~b}$ \\
\hline 6 & $15.97 \mathrm{c}$ & $25.12 \mathrm{a}$ & $14.85 \mathrm{~cd}$ & $18.31 \mathrm{a}$ \\
\hline 9 & $14.85 \mathrm{~cd}$ & $19.87 \mathrm{~b}$ & $11.20 \mathrm{de}$ & $15.31 \mathrm{~b}$ \\
\hline Mean & $13.78 \mathrm{~b}$ & $21.80 \mathrm{a}$ & $11.76 \mathrm{~b}$ & \\
\hline
\end{tabular}

Each value is the mean of three replications. Mean values following by the different letters show significant differences $(\mathrm{p} \leq 0.05)$. For $2,4-\mathrm{D}$, LSD value was 2.22 at $\mathrm{p} \leq 0.05$. For soaking time, LSD value was 2.22 at $\mathrm{p} \leq 0.05$, while for interaction of $2,4-\mathrm{D}$ and soaking time, LSD was 3.86 at $\mathrm{p} \leq 0.05$

\section{Optimization of apical meristem incubation method for in planta transformation}

Table 2 shows that three hundred seeds were surface sterilized for each experiment i.e. inoculation before and after germination of apical meristem. Out of which 250 and 263 seeds were co-cultivated, respectively. After co-cultivation, these seeds were washed with MS liquid media having $500 \mathrm{mg} / \mathrm{l}$ cefotaxime then transferred to regeneration media. The regeneration frequency was 48 and $40.68 \%$ when seeds were inoculated before and after 
germination, respectively (Table 2). In case of inoculation after germination, apical meristem was blindly injured through cut end of coleoptiles, so it might be damaged cells of mother germ lines due to which regeneration frequency was low, while in case of before germination embryo was visible and was easily targeted for injury. These results suggested that injury of apical meristem before germination of apical meristem was better than that of after germination. Injury should be made very carefully so that germ line mother cells remained safe from damaging. Hygromycin $(50 \mathrm{mg} / \mathrm{l})$ was used in selection media and 25 and $0 \%$ hygromycin resistant plants were obtained from seeds which were inoculated before and after germination, respectively (Table 2).

Table 2. Assessment of inoculation method for incubating apical meristem before and after seed germination

\begin{tabular}{c|c|c}
\hline In planta transformation steps & $\begin{array}{c}\text { Inoculation of apical } \\
\text { meristem before seed } \\
\text { germination }\end{array}$ & $\begin{array}{c}\text { Inoculation of apical } \\
\text { meristem after seed } \\
\text { germination }\end{array}$ \\
\hline Number of treated seeds & 300 & 300 \\
Number of co-cultivated seeds & 250 & 263 \\
Number of regenerated seeds & 120 & 107 \\
Regeneration percentage & $48 \%$ & $40.68 \%$ \\
Number of hygromycin resistant plants & 30 & Nil \\
Hygromycin resistant percentage & $25 \%$ & Nil \\
Number of seeds sown in T generation & 50 & Nil \\
Number of germinated seeds & 47 & Nil \\
PCR positive plants & 3 & Nil \\
Transformation efficiency & $6.38 \%$ & $0 \%$ \\
\hline
\end{tabular}

Transformation efficiency was measured by the number of PCR positive plants divided by the total number of explants cultured on selection medium, expressed in percentage

\section{Molecular analysis of wheat transgenes}

Seeds of hygromycin resistant plants ( $\mathrm{T}_{0}$ generation) were pooled, out of which only 50 seeds were sown due to limited space and $\mathrm{T}_{1}$ generation was obtained. 47 seeds were germinated and when seedlings were at 2 to 3 leaf stage, they were confirmation by PCR using DREBIA specific primers. The results indicated that 3 plants were PCR positive showing transformation efficiency of $6.38 \%$ (Table 2; Fig. 2b). These plants were also found positive by PCR using hpt specific primers (Fig. 2c). In order to assess the inheritance pattern of transgene, segregation analysis was performed by normal PCR using DREBIA specific primers. The segregation ratio of three transgenic plants has been shown in Figure 3. The data indicated that segregation ratio was 5:5, 4:5 and 2:7 in $\mathrm{K} 1, \mathrm{~K} 2$ and $\mathrm{K} 3$ transgenic plants, respectively that exhibited non-Mendalian inheritance pattern (Table 3). Trizole reagent was used for isolation of RNA from the leaves of transformed plants. cDNA synthesized from RNA was used for amplification of DREBIA gene through PCR using gene specific primers. The results show the differential expression pattern of transgenic plants i.e. some transgenic plants gave good expression, while few produced weak expression (Fig. 4). Southern blotting was done to detect the number of copies of desired gene in three transgenic plants (K1, K2 and K3) that indicated 1-2 copies of gene (Fig. 5). 
A PBIH-35S:DREB1A

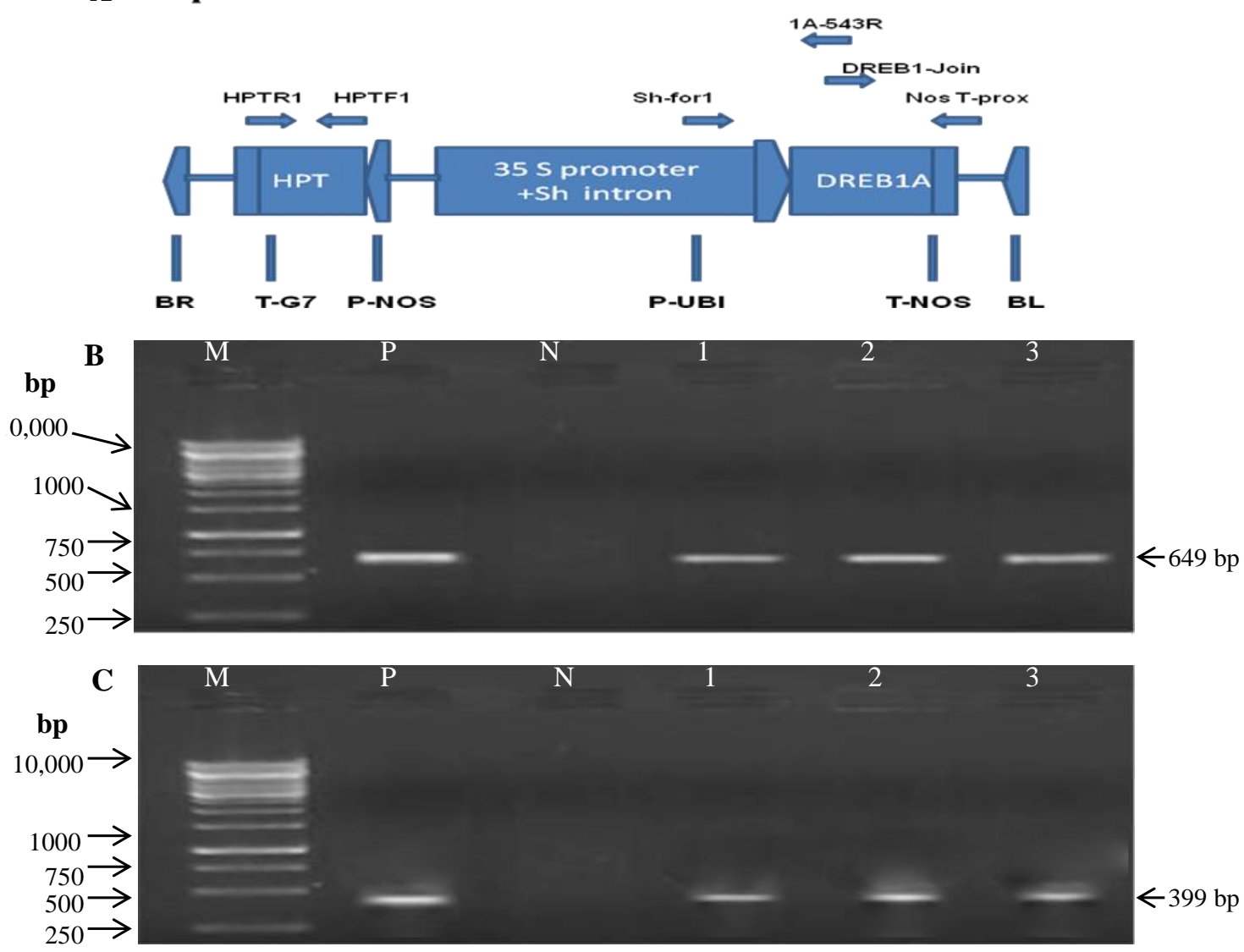

Figure 2. Confirmation of $T_{0}$ and $T_{l}$ wheat transgenic plants for the existence of DREB1A (649 bp) and hpt (399 bp) genes within their genomes. A Construct diagram containing DREB1A under 35S promoter. LB: Left border, RB: Right border, T-G7; Terminator, hpt: Hygromycin phosphotransferase gene, T-NOS and P-NOS (terminator and promoter sequences of nopaline synthase gene) (Source: NIGAB, NARC Islamabad, Pakistan). B PCR analysis showing transgenic plants of wheat possessing DREB1A gene (649 bp) using Agrobacterium strain EHA101 (carrying binary plasmid PCAMBIA); Lane M shows $1 \mathrm{~kb}$ DNA Ladder (Fermentas),

Lane $P$ shows positive control (plasmid pCAMBIA), Lane $N$ shows negative control (nontransgenic wheat). Lanes show 1-3 transgenic plants of wheat. C PCR analysis for presence of hpt gene (399 bp fragment size); Lane M 1 kb DNA Ladder (Fermentas). Lane P positive control (plasmid pCAMBIA), Lane N negative control (non-transgenic wheat), Lanes 1-3 transgenic plants of wheat

\section{Germination of $T_{2}$ transgenic plants improved in response to drought stress}

The seeds of the transgenic plants were tested for germination frequency and germination rate index. The transgenic and control seeds were placed on filter paper soaked with different concentrations of PEG solution (-2, -4, -6 and -8 bar osmotic stress) to induce artificial drought stress under controlled condition. Figure 6 indicated that the transgenic and control plants had significant difference $(\mathrm{P}=0.0000)$ at $5 \%$ alpha level. Similarly, a significant difference among different treatments of PEG stress as well as among the interaction of transgenic plants, control plants and PEG stress for germination frequency and germination rate index. But there was non-significant difference $(P=0.2607)$ in terms of the interaction of plants and PEG stress at $5 \%$ alpha 
level. The results showed that the highest germination frequency (94.97\%) was recorded in transgenic plants as compared to control plants (80.83\%) at -2 bar osmotic stress (Fig. 6). Similarly, more germination rate index (5.5) was found in transgenic plants than that of control plants that yielded 2.8 germination rate index (Fig. 7).
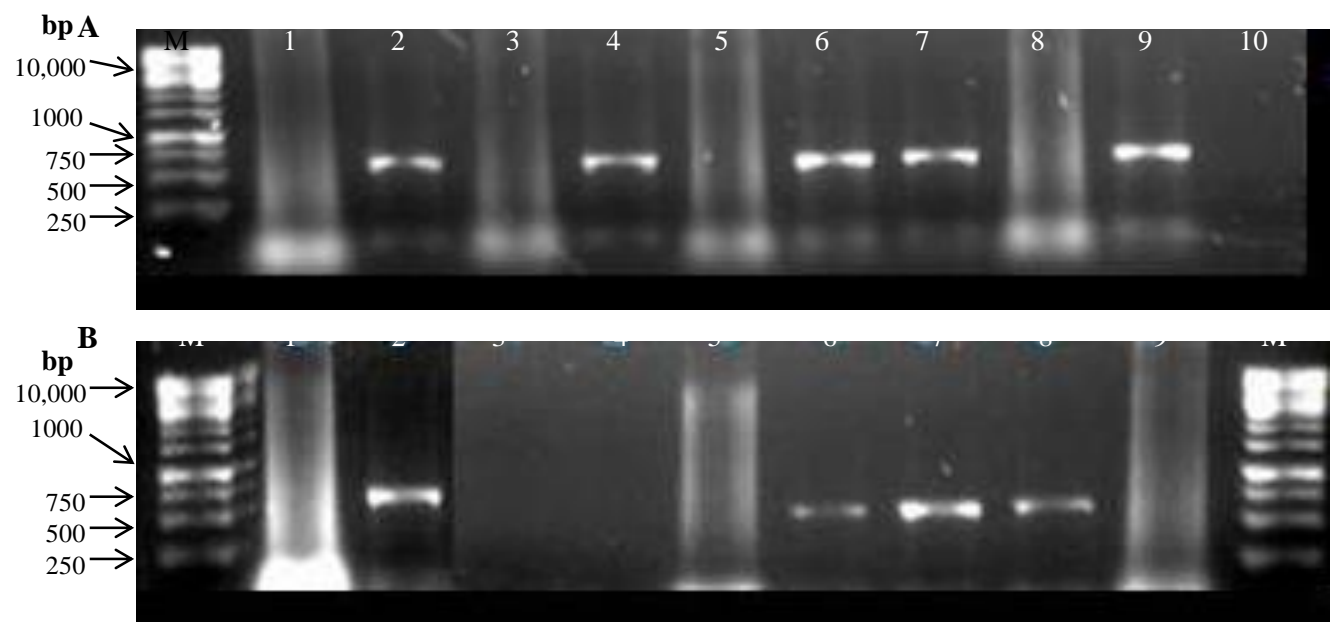

C

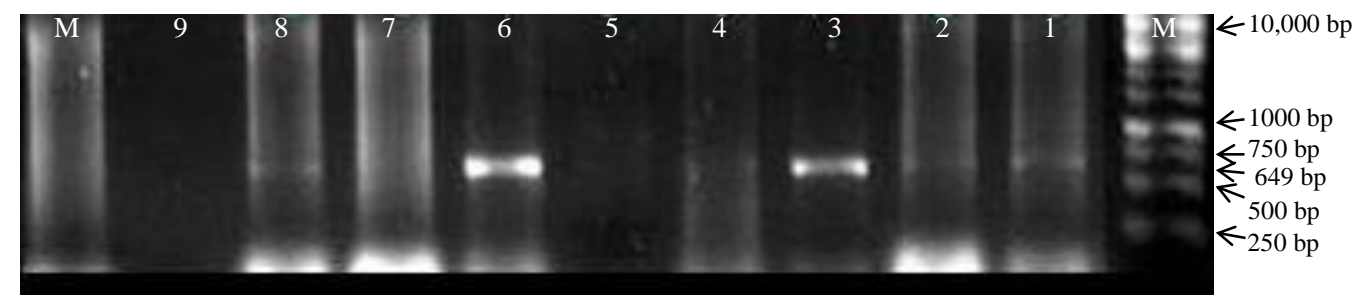

Figure 3. Segregation analysis of three transgenic plants of wheat (K1, K2 and K3). Seeds obtained from $T_{1}$ transgenic plants were sown in pots for $T_{2}$ generation. Segregation pattern of DREBIA gene was noticed through PCR using DREBIA specific primers. The segregation ratio was 5: 5, 4: 5 and 2: 7 for three transgenic plants K1, K2 and K3, respectively. The total 28 plants of $T_{2}$ generation were tested through PCR for the presence of DREBIA gene using DREB1A specific primers. Results shows that out of these tested plants, 11 plants were PCR positive having DREBIA gene in their genomes. It indicates that transformation was successful in these plants and gene was stably inherited into $T_{2}$ generation

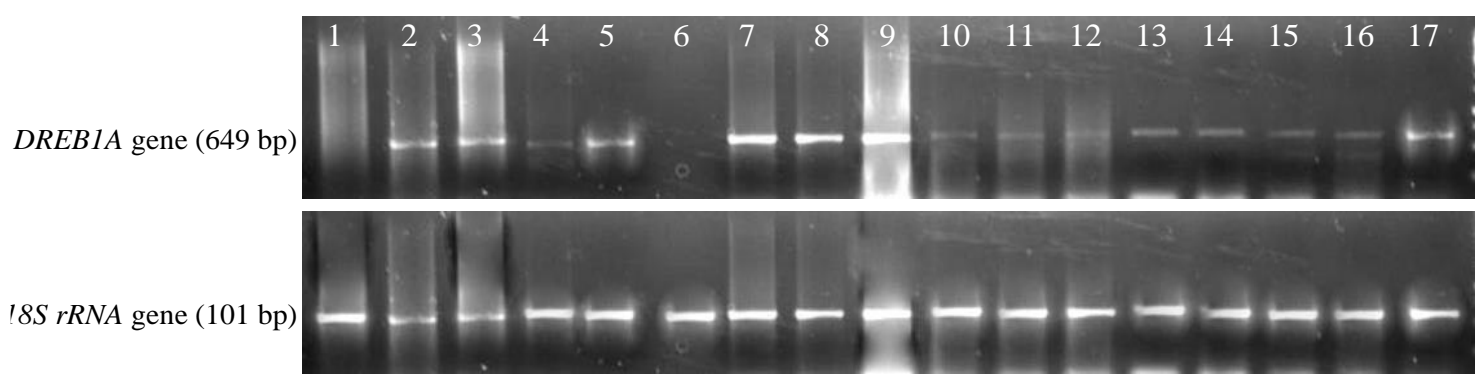

Figure 4. Expression of DREB1A gene in leaf tissues of $T_{2}$ transgenic plants at various levels by semi-quantitative RT-PCR. Here, 18S rRNA gene was used as an internal control. Lane 1 is demonstrating amplicon from control wheat plants. Lanes 2-6 are demonstrating amplicon from K1 transgenic plants. Lanes 7-12 are demonstrating amplicon from K2 transgenic plants. Lanes 13-17 are demonstrating amplicon from $\mathrm{K} 3$ transgenic plants 


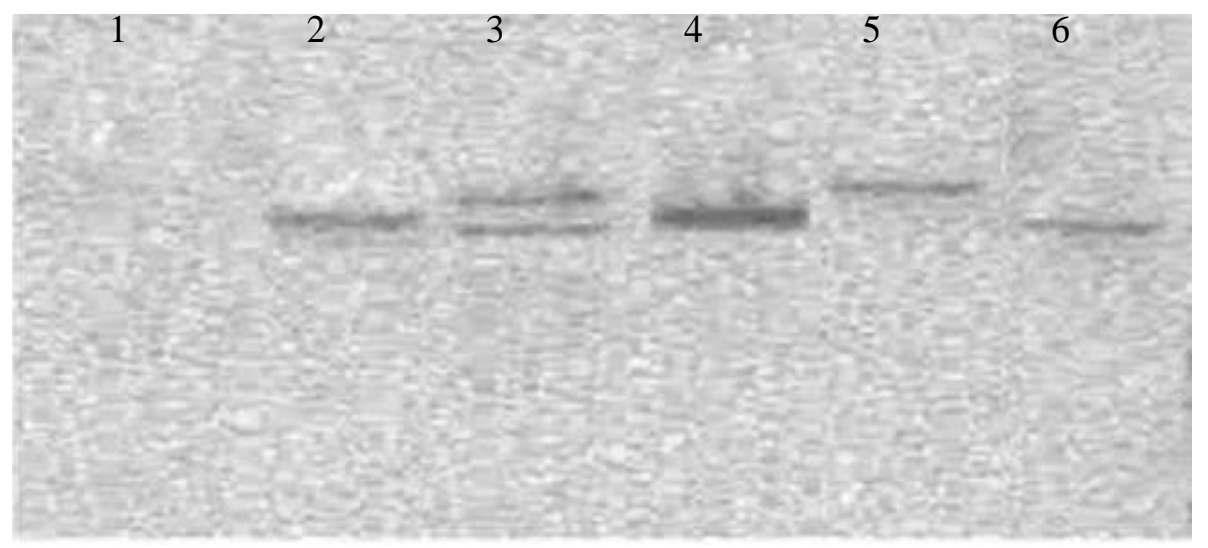

Figure 5. Southern blotting of $T_{2}$ wheat transgenic plants using HindIII endonuclease for DNA digestion of transgenic and control plants and hybridized with DREBIA-Fermentas Biotin DecaLabel probe. Lane 1 is showing negative control (non-transgenic plants), Lane 2 is showing transgenic plants K1, Lanes 3-4 are showing transgenic plants K2, Lanes 5-6 are showing transgenic plants $K 3$

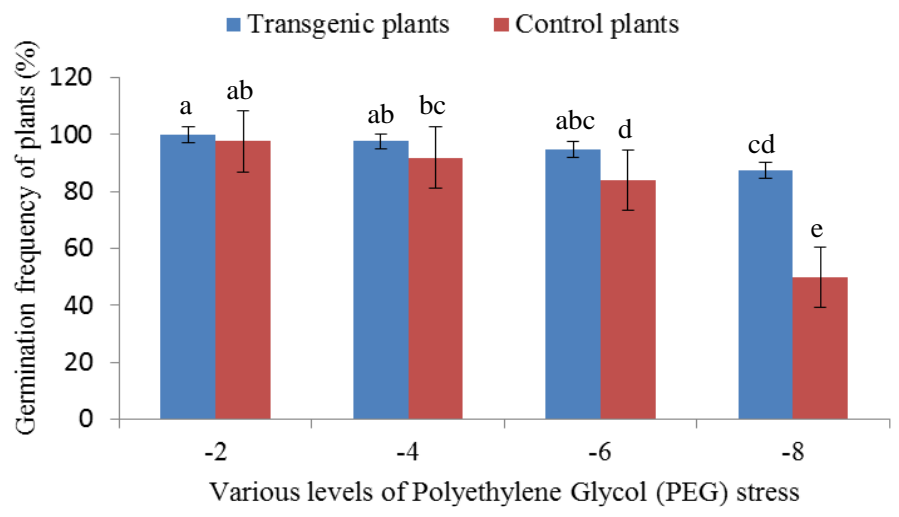

Figure 6. Effect of various levels of Polyethylene Glycol (PEG) stress on germination frequency $(\%)$ of transgenic and control plants of wheat. The error bars indicate standard error. Means not sharing a letter in common differ significantly at 5\% probability level

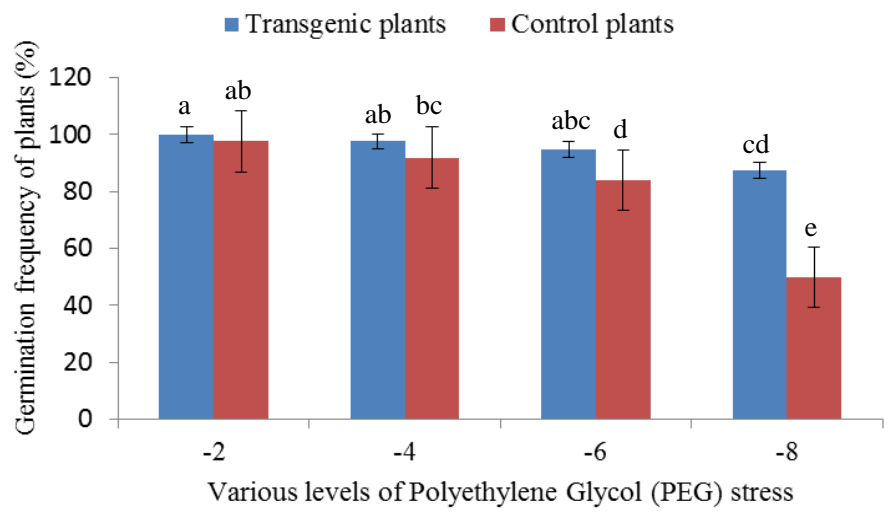

Figure 7. Effect of various levels of Polyethylene Glycol (PEG) stress on germination rate index of transgenic and control plants of wheat. The error bars indicate standard error. Means not sharing a letter in common differ significantly at 5\% probability level 
Table 3. Segregation analysis of transgenic plants produced by in planta transformation method

\begin{tabular}{c|c|c|c|c}
\hline $\begin{array}{c}\text { Transgenic } \\
\text { plants }\end{array}$ & $\begin{array}{c}\text { Total no. of plants } \\
\text { tested }\end{array}$ & $\begin{array}{c}\text { PCR positive } \\
\text { plants }\end{array}$ & $\begin{array}{c}\text { PCR negative } \\
\text { plants }\end{array}$ & Segregation ratio \\
\hline K1 & 10 & 5 & 5 & $5: 5$ \\
K2 & 9 & 4 & 5 & $4: 5$ \\
K3 & 9 & 2 & 7 & $2: 7$ \\
Total & 28 & 11 & 17 & $11: 17$ \\
\hline
\end{tabular}

\section{Length of shoots, roots and coleoptiles of $T_{2}$ transgenic plants improved in response to drought stress}

Seedling stage is an appropriate stage for testing drought stress tolerance using PEG8000 in laboratory condition. During this study, it was confirmed that the increased concentration of PEG prevented the growth, and survival of seedling and PEG concentration was found to be inversely proportional to the shoot length. After 8 days, it was noticed that the lethal effect was more prominent in control plants as compared to transgenic plants. The data in Figures 8-10 indicate that shoots, roots and coleoptiles length of transgenic plants were significantly different to control plants (non-transgenic plants). The results showed that the shoots, roots and coleoptiles length of transgenic plants were $13.11,5.77$ and $5.6 \mathrm{~cm}$, respectively at -2 bar osmotic stress as compared to their non-transgenic counterparts that showed 12.46, 3.27 and $3.3 \mathrm{~cm}$ shoots, roots and coleoptiles length. While at -8 bar osmotic stress, the transgenic plants gave 7.49, 5.4 and $2.93 \mathrm{~cm}$ shoot, root and coleoptile lengths which were comparable to their nontransgenic counterparts that produced $3.47,1.84$ and $1.64 \mathrm{~cm}$ shoot, root and coleoptiles lengths. Our results showed that shoots, roots and coleoptiles length reduced with the increase in the stress level. But this reduction was more prominent in control plants.

\section{Increased relative water contents of $T_{2}$ transgenic plants under drought stress}

Water is a limiting factor for plant growth and development. It maintains the turgor pressure in plant cells and involves in all physiological function of plants. So, the plants which maintain the high relative water contents in their cells have good performance under drought stress as compared to the plants having low water contents (Ali et al., 2015). In this regard relative water content was measured in transgenic and control plants at germination stage inducting the drought stress through PEG, while at vegetative stage drought stress was induced withholding water for $8 \mathrm{~d}$. The significant difference $(\mathrm{P}=0.0000)$ were recorded between transgenic and control plants and interaction of transgenic and control plants with PEG stress (Fig. 11). The highest relative water contents $(92.28 \%)$ were recorded in transgenic plants as compared to control plants (76.63\%) at -2 bar osmotic stress. When PEG stress increased then RWC decreased significantly in control as well as in transgenic plants. But in transgenic plants RWC was not reduced significantly as osmotic stress increased from -2 to -4 bar osmotic stress. Figure 12 shows the significant difference $(\mathrm{P}<0.05)$ between treatments, cultivars (Transgenic and control plants) but non-significant difference $(\mathrm{P}=0.210)$ in terms of interaction among treatments and cultivars (Transgenic and control plants). During this experiment, drought stress was induced withholding water for $8 \mathrm{~d}$. The highest relative 
water contents $(67.46 \%)$ was found transgenic plants which were comparable to those of control plants that yielded $40 \%$ relative water contents (Fig. 12).

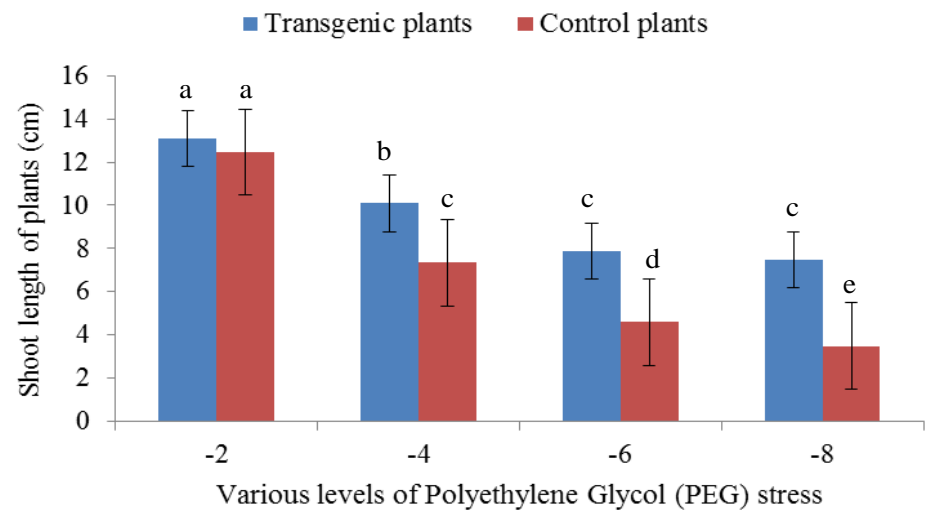

Figure 8. Effect of various levels of Polyethylene Glycol (PEG) stress on shoot length ( $\mathrm{cm}$ ) of transgenic and control plants of wheat. The error bars indicate standard error. Means not sharing a letter in common differ significantly at 5\% probability level

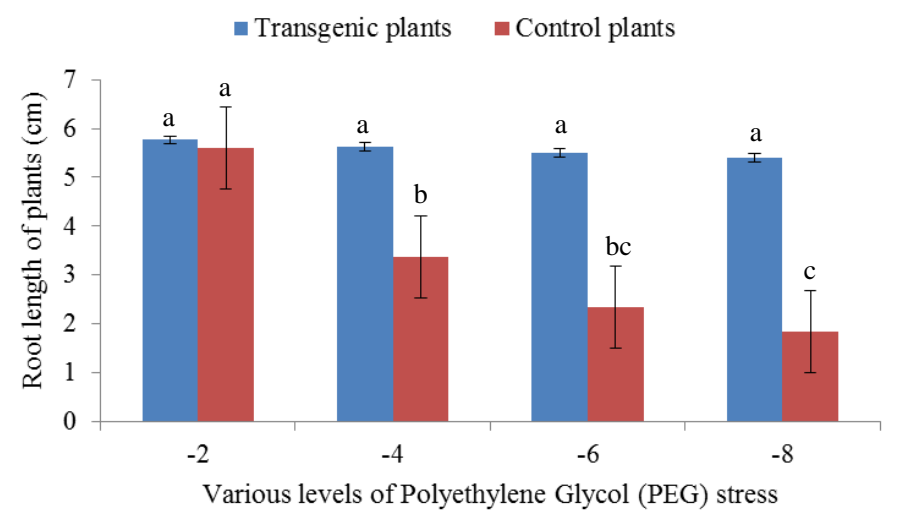

Figure 9. Effect of various levels of Polyethylene Glycol (PEG) stress on root length (cm) of transgenic and control plants of wheat. The error bars indicate standard error. Means not sharing a letter in common differ significantly at 5\% probability level

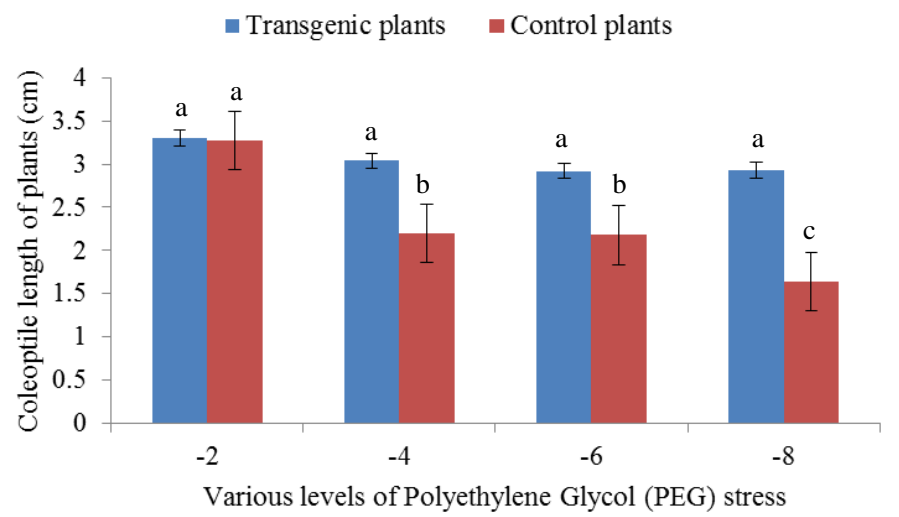

Figure 10. Effect of various levels of Polyethylene Glycol (PEG) stress on coleoptile length $(\mathrm{cm})$ of transgenic and control plants of wheat. The error bars indicate standard error. Means not sharing a letter in common differ significantly at 5\% probability level 


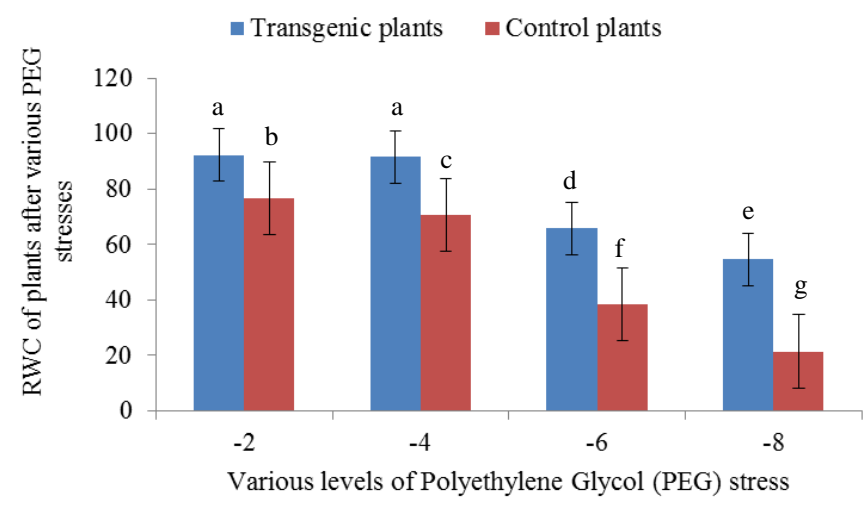

Figure 11. Effect of various levels of Polyethylene Glycol (PEG) stress on relative water contents $(\%)$ of transgenic and control plants of wheat. The error bars indicate standard error.

Means not sharing a letter in common differ significantly at 5\% probability level

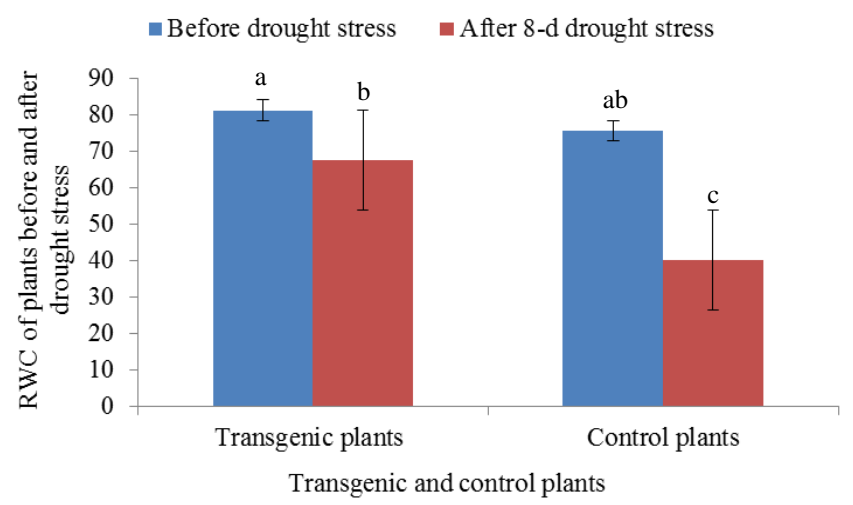

Figure 12. Effect of 8-d drought stress on relative water contents (\%) of transgenic and control plants of wheat. The drought stress was induced by withholding water for continuous 8-d and then drought tolerance was assessed in transgenic plants on the basis of relative water contents

(\%). The error bars indicate standard error. Means not sharing a letter in common differ significantly at $5 \%$ probability level

\section{Proline contents of $T_{2}$ transgenic plants improved in response to drought stress}

Osmotic adjustment is the mechanism of drought tolerance in which plant cells accumulate different osmoprotectants such as polyols, proline, proteins and polyols etc. These osmoprotectants protects the cells membranes from stress conditions (Filippou et al., 2014). These compounds accumulated in higher quantities under stressed condition and acted as osmoprotectants (Strange and Yancey, 1994), among these, proline (amino acid) enhances the stability of proteins and membranes under water stress conditions (Anjum et al., 2017). Moreover; its concentration increased with the increase in drought levels (Mujtaba et al., 2007). Figure 13 shows the significant difference $(\mathrm{P}<0.05)$ between transgenic plants and control plants in terms of proline contents and a significant difference between treatments as well as between the interaction of cultivars (transgenic and control plants) and treatments (drought stress by withholding water). The data showed that proline contents increased significantly in transgenic and control plants after drought stress. This increase in proline contents from $1.03 \mu \mathrm{mol} / \mathrm{g}$ to $7.06 \mu \mathrm{mol} / \mathrm{g}$ that was more prominent and significant in transgenic plants as compared 
to control plants $(0.86 \mu \mathrm{mol} / \mathrm{g}$ to $3.50 \mu \mathrm{mol} / \mathrm{g})$ under normal and drought conditions, respectively. The reason of this higher accumulation of proline contents in transgenic plants might be due to function of DREBIA gene that triggers the other genes related to mechanism of production of proline under drought stress. The higher proline contents in transgenic plants indicated that these are more drought tolerance than control plants.

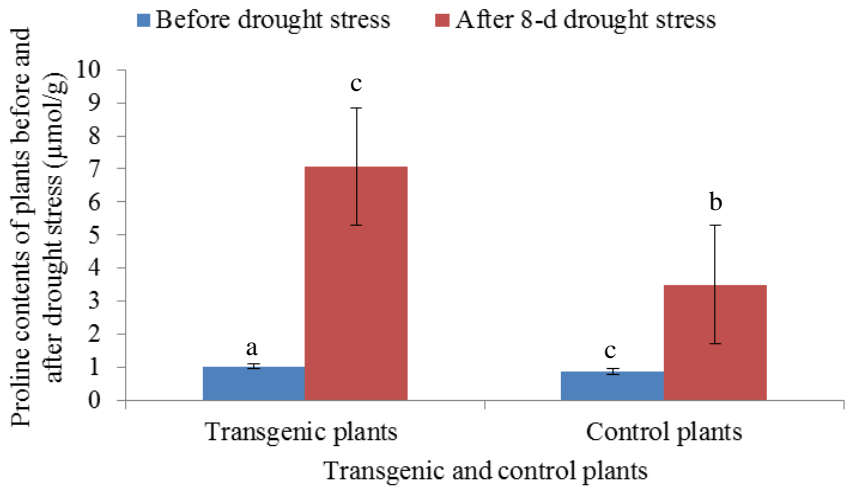

Figure 13. Effect of 8-d drought stress on proline contents ( $\mu \mathrm{mol} / \mathrm{g} F W$ ) of transgenic and control plants of wheat. The drought stress was induced by withholding water for continuous 8$d$ and then drought tolerance was assessed in transgenic plants on the basis of proline contents ( $\mu \mathrm{mol} / \mathrm{g} F W)$. The error bars indicate standard error. Means not sharing a letter in common differ significantly at $5 \%$ probability level

\section{Increased chlorophyll contents of $T_{2}$ transgenic lines after drought stress}

Chlorophyll is the most effective parameter for the selection of drought tolerant wheat genotype under drought stress conditions (Rad et al., 2012). The data in Figures 14-16 showed that the chlorophyll contents decreased non- significantly in transgenic plants (before and after drought stress), while they were decreasing significantly in control plants. The significant difference of chlorophyll contents was recorded between transgenic and control plants after drought stress. These results indicated that transgenic plants have capability to sustain their chlorophyll contents in drought stress and behave as drought tolerant wheat plants as compared to control plants. This capability of transgenic plants was developed due to the function of $D R E B 1 A$ gene in their genome.

\section{Improved agronomic characteristics of $T_{2}$ transgenic plants in term of drought tolerance efficiency}

The Table 4 showed the significant differences $(\mathrm{P}<0.05)$ between treatments as well as between transgenic lines and control plants for the parameters (spike length, grains per spike and 100-grains weight). The Table 4 shows the comparison of transgenic plants with no-transgenic plants (control plants). It was observed that in normal conditions, spike length $(10.7 \mathrm{~cm})$, grain per spike (57) of transgenic plants was significantly higher than non-transgenic plants i.e. $10.2 \mathrm{~cm}$ (spike length) and 53 (grains per spike), respectively. Similarly, weight of 100 grains (4.72 g) of transgenic lines was a little bit higher than non-transgenic plants $(4.63 \mathrm{~g})$. But in case of drought conditions the reduction in spike length, 100 grains weight and grains per spike were much lower in transgenic plants as compared to non-transgenic plants (Table 4). 


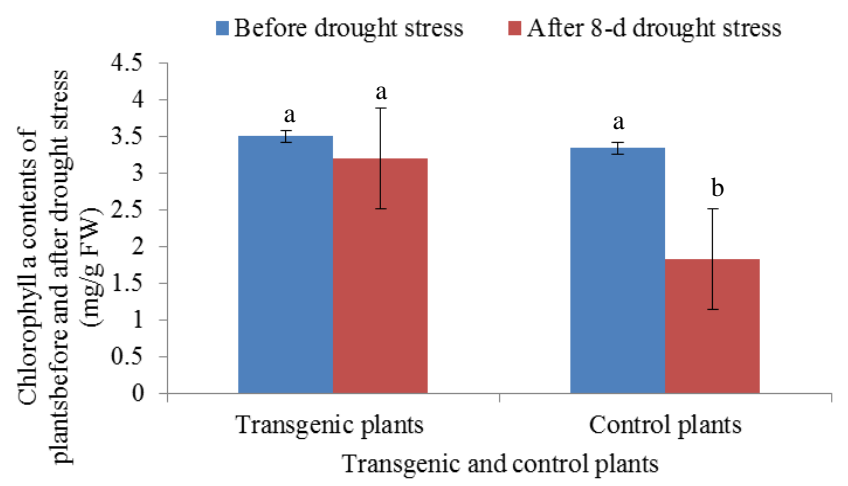

Figure 14. Effect of 8-d drought stress on chlorophyll a contents $(\mathrm{mg} / \mathrm{g} \mathrm{FW}$ ) of transgenic and control plants of wheat. The drought stress was induced by withholding water for continuous 8$d$ and then drought tolerance was assessed in transgenic plants on the basis of chlorophyll a contents $(\mathrm{mg} / \mathrm{g} \mathrm{FW})$. The error bars indicate standard error. Means not sharing a letter in common differ significantly at 5\% probability level

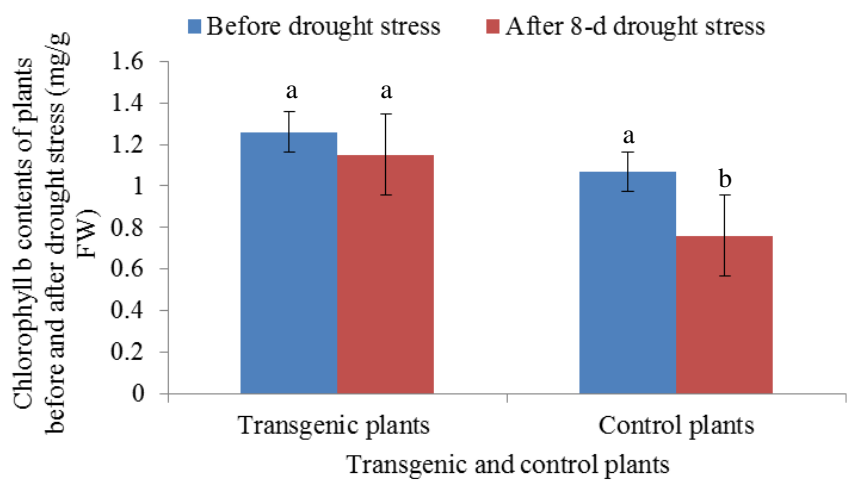

Figure 15. Effect of 8-d drought stress on chlorophyll b contents $(\mathrm{mg} / \mathrm{g} \mathrm{FW})$ of transgenic and control plants of wheat. The drought stress was induced by withholding water for continuous 8$d$ and then drought tolerance was assessed in transgenic plants on the basis of chlorophyll $b$ contents $(\mathrm{mg} / \mathrm{g} \mathrm{FW})$. The error bars indicate standard error. Means not sharing a letter in common differ significantly at 5\% probability level

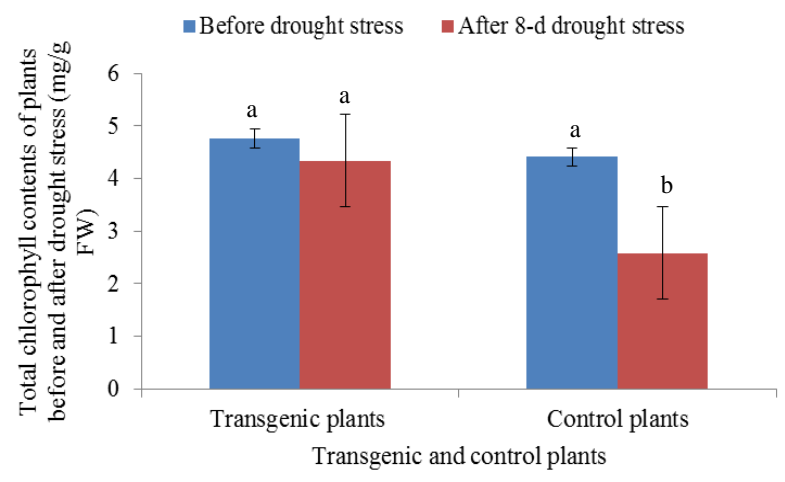

Figure 16. Effect of 8-d drought stress on total chlorophyll contents $(\mathrm{mg} / \mathrm{g} F \mathrm{~F})$ of transgenic and control plants of wheat. The drought stress was induced withholding water for continuous

8-d and then drought tolerance was assessed in transgenic plants on the basis of total chlorophyll contents $(\mathrm{mg} / \mathrm{g} \mathrm{FW})$. The error bars indicate standard error. Means not sharing a letter in common differ significantly at $5 \%$ probability level 
Table 4. Improved agronomic characteristics and drought tolerance efficiency of transgenic plants

\begin{tabular}{c|c|c|c|c}
\hline \multirow{2}{*}{ Characteristics } & \multicolumn{2}{|c|}{ Transgenic plants } & \multicolumn{2}{c}{ Control plants } \\
\cline { 2 - 5 } & $\begin{array}{c}\text { Normal } \\
\text { condition }\end{array}$ & $\begin{array}{c}\text { Drought } \\
\text { stress }\end{array}$ & $\begin{array}{c}\text { Normal } \\
\text { condition }\end{array}$ & $\begin{array}{c}\text { Drought } \\
\text { stress }\end{array}$ \\
\hline Spike length (cm) & $10.7 \mathrm{a}^{* *}$ & $9.6 \mathrm{c}$ & $10.2 \mathrm{~b}$ & $8.5 \mathrm{~d}$ \\
Number of seeds per spike & $57 \mathrm{a}$ & $46 \mathrm{c}$ & $53 \mathrm{~b}$ & $31 \mathrm{~d}$ \\
100-grain weight (g) & $4.72 \mathrm{a}$ & $4.25 \mathrm{~b}$ & $4.63 \mathrm{a}$ & $2.15 \mathrm{c}$ \\
Drought tolerance efficiency (DTE) & $90 \% *$ & \multicolumn{3}{|c}{$46.43 \%$} \\
\hline Improvement in DTE & \multicolumn{2}{|c|}{ DTE of transgenic plants - DTE of control plants = (90) - } \\
\end{tabular}

Each value is the mean of three replications. For comparison of spike length, LSD value was 0.36 at $p \leq 0.05$. For comparison of number of seeds per spike, LSD value was 4.32 at $p \leq 0.05$, while for comparison of 1000-grain weight; LSD value was 0.1001 at $\mathrm{p} \leq 0.05$. *Calculation based on 100-grain weight in normal and stress condition. **Means not sharing a letter in common differ significantly at $5 \%$ probability level

Drought tolerance efficiency (DTE) is a criterion to compare drought tolerance cultivars. It was proposed by Fisher and Wood (1981). It is a good index for determination of drought tolerant wheat cultivars. So, this index was used for transgenic plants and control plants. The data in Table 4 showed that the drought tolerance efficiency of transgenic plants (90\%) was much higher than control plants (46.43\%). So, the total improvement in DTE of transgenic plants was $43.57 \%$. This increase in drought tolerance efficiency was due to the presence of DREBIA gene in transgenic plants. This transcription factor might trigger other genes to produce such proteins which protect the plants from drought stress and also maintain the water balance in cells of leaves. So, as a result chlorophyll contents stable in leaves and maximum food were synthesized which was stored in the form of grains. It was also used as criteria for drought and heat resistance in spring wheat (Bahar and Yildrim, 2010) they reported the range of $65-98 \%$ (DTE \%) in drought tolerance wheat cultivars.

\section{Discussion}

Wheat ensures the food security of the world, but it is severely affected by scarcity of water due to limited water resources. Drought can occur at any developmental stage of wheat that drastically limits its yield. Plants have to adopt some tolerance mechanisms to endure the severity of water shortage. Genetic improvement of wheat can cope with drought problem using Agrobacterium-mediated method. Dehydration-responsive element-binding 1A (DREB1A) gene enhances the drought tolerance ability of transgenic plants activating the expression of drought related target genes (Oh et al., 2005). In planta method of genetic transformation is a technique of gene transformation which has low cost, does not require sterilized environment and it avoids laborious hardworking tissue culture steps.

During this study, inoculation before seed germination was found to be optimum for maximum transformation efficiency of in planta transformation because inoculation media fortified with $3.0 \mathrm{mg} / \mathrm{l}$ 2, 4-D decreased the cell division and delayed the process of differentiation. As a result, Agrobacterium got maximum time to transfer its T-DNA 
to apical meristem cells. While in case of inoculation after germination, seeds were soaked in distilled water only without 2, 4-D, so no transformation was obtained. The cell division and differentiation processes in meristematic cells increased rapidly with the increase of soaking time due to which the probability of infection to cells by Agrobacterium was decreased. These processes needed to be slow down for infection of target cells by Agrobacterium (Razzaq, 2005). The piercing of meristematic cells with needle facilitates Agrobacterium to reach and infect the germ line mother cells. In case of inoculation after germination, no hygromycin resistant plants were visualized indicating that there would be two possibilities; first was damaging cells of mother germ lines and second was that Agrobacterium could not reach and infect the germ line mother cells due to large number of layers of cells formed on outer surface of germ line mother cells. On the contrary, $25 \%$ hygromycin resistant plants were obtained in case of inoculation before germination indicating that at this time, germ line mother cells could easily be targeted and Agrobacterium could easily reach and infected the target cells. The similar studies were reported by Razzaq et al. (2005) who conducted in planta transformation of wheat and sixty-three kanamycin resistant plants were reported. Out of these sixty-three plants, only three plants were PCR positive and one plant produced seeds. Bratic (2007) transformed the buckwheat via in planta transformation and compared the efficiency of two different procedures, i.e. vacuum infiltration and infiltration by syringe. It was concluded that vacuum infiltration was more efficient than that of infiltration by syringe. Rao et al. (2008) reported in planta transformation of pigeon pea in which primary transformants were chimeric in nature. Due to this reason, $\mathrm{T}_{0}$ plants were not tested for the confirmation of gene through PCR. PCR was performed in $\mathrm{T}_{1}$ generation and $13.71 \%$ transformation efficiency was reported. Cheng et al. (2003) analyzed the transgenic wheat by southern blotting and reported that $67 \%$ transgenic wheat plants obtained a single copy of transgene. Yao et al. (2006) developed transgenic wheat and reported that in transgenic line, one to four hybridizing bands were displayed, but most of the lines showed single copy of inserted genes. In present study inheritance pattern of transgene was shown as non-Mendelian ratio. Similarly, Yin et al. (2004) reported 10-50\% transgenic plants showing non-Mendelian inheritance; either they were produced by gene gun or Agrobacterium mediated transformation. They concluded that this non-Mendelian segregation ratio might be due to the nature of the gene and recipient genome.

The results of our study suggested that DREBIA gene improved the germination frequency and germination rate index of transgenic seeds as compared to the seeds of control plants. Early and best germination rate of any crop is a pre-requisite to establish new seedlings. The problem of low germination of seeds exists in most of the wheat cultivars especially when moisture level in soil is very low. Water stress limits the germination frequency, germination rate index as well as emergence of seedling due to loss of seed vigor. During this study, it was also noticed that all transgenic seeds obtained from in planta Agrobacterium tumefaciens mediated transformation showed non-uniform germination under different PEG stresses. It was due to segregation of DREB1A. Our findings are supported by the results of Pellegrineschi et al. (2004); Kasuga et al. (1999) who conducted research studies in wheat and Arabidopsis, respectively and found non-uniform germination. Germination rate index and germination frequency were higher in seeds of transgenic plants as compared to control plants. These were considered good parameters for screening drought tolerant wheat cultivars. Our results also revealed that with increasing PEG stress levels, germination 
frequency and germination rate index were decreased. Our findings are harmonious with the earlier research study by Qayyum et al. (2011) who reported that germination time and germination frequency became low with increasing level of osmotic stress from 0 to -8 bars induced by PEG.

High relative water contents are a resistance mechanism to tackle drought stress (Ritchie et al., 1990). So, relative water content is a tool to discriminate drought sensitive and drought resistant wheat cultivars (Fahliani and Assad, 2005). Amirjani and Madhiyeh (2013) and Bayoumi et al. (2008) induced drought stress under field conditions withholding water and noticed that drought tolerance wheat cultivar had higher relative water contents as compared to drought susceptible wheat cultivar. Our findings were similar with the findings of Raziuddin et al. (2010) who reported that drought tolerance wheat cultivars attained maximum relative water contents as compared to other cultivars during stress induced by PEG 6000. Similarly, Rab et al. (2012) assessed the drought tolerance and drought sensitive wheat cultivars hydroponically by inducing drought through 20\% PEG and found higher relative water contents (RWC) at cellular levels in drought tolerance wheat cultivar as compared to drought sensitive one. Drought tolerant wheat cultivars maintained higher RWC in their leaves as compared to drought sensitive cultivars (Keyvan, 2010). Ritchie et al. (1990) reported that RWC were stable in early days of water stress in both drought tolerant and drought sensitive genotypes but it decreased significantly after 8 days of water stress in drought sensitive genotypes. From these results it was concluded that transgenic plants exhibited high relative water contents due to overexpression of DREBIA gene.

Our findings are consistent with the findings of Qayyum et al. (2011) who reported the progressive increase of proline contents with the increase of osmotic stress from 0 to -08 bar. Similarly, Raziuddin et al. (2010) reported that when PEG-6000 was used to induce drought stress, proline contents increased up to 10 fold in response to $40 \%$ PEG. Bayoumi et al. (2008) reported that drought tolerant wheat cultivar had higher proline contents as compared to drought susceptible cultivars. A similar nature of study was conducted by Moaveni (2011) who recorded more accumulation of proline contents in transgenic wheat plants under drought stress as compared to control plants. Valifard et al. (2012) classified two wheat varieties i.e. Zagros (drought tolerant) and Pishtaz (drought susceptible) and reported that proline increased significantly in tolerant one. These results indicate that proline is a part of defense mechanisms which confers water deficit tolerance to wheat cultivars. The increase of proline contents under drought stress has been reported in previous research studies such as Pigeonpea (Kumar et al., 2011), Brassica (Khan et al., 2010) and bean (Stoyanov, 2005) suggesting that it is a common osmolyte which accumulated in drought conditions. Moussa and Abdel-Aziz (2008) reported that the drought tolerant maize genotype "Giza-2" had accumulated more proline contents than that of drought sensitive maize genotype "Trihybrid-321". Proline improves the drought tolerance at cellular level by stabilizing cytosolic $\mathrm{pH}$, protecting protein and enzyme structure, providing organic nitrogen for growth and survival of plants and also acts as a source of energy (Hare et al., 1999; Errabii et al., 2006; Ashraf and Foolad, 2007; Bayoumi et al., 2008).

Present study reports an enhanced accumulation of chlorophyll contents in transgenic wheat plants as compared to their control counterparts under drought stress. Our results of transgenic plants do not agree with the results of Amirjani and Madhiyeh (2013). This research group reported a significant reduction of total chlorophyll contents in transgenic plants under drought stress. In our study, improvement of chlorophyll 
contents in transgenic plants might be due to overexpression of DREB1A gene triggering drought tolerant genes that produce certain proteins due to which stability of chlorophyll contents was recorded in them as compared to control plants. Consistent with our findings, Moaveni (2011) assessed drought tolerance efficiency of wheat by measuring chlorophyll contents and reported that chlorophyll contents were significantly improved in transgenic plants as compared to control plants. The chlorophyll contents were significantly higher in transgenic plants as compared to control plants. The philosophy of increased chlorophyll contents in transgenic plants might be possible that DREB1A transcription factors switch on others genes producing chemicals that lower the stress level, protect the plant cells and maintain the water balance in cells. While in control plants, chlorophyll contents were limited due to water stress and they could not maintain their structures. The chlorophyll contents are considered as a good parameter to differentiate drought tolerance and drought sensitive germplasms (Rong-Hua et al., 2006). Drought stress decreased the level of water in mesophyll cells of leaves and as a result chlorophyll pigment degraded and damaged the photosynthetic machinery (Bogale et al., 2011).

Drought susceptible index (DSI) and drought resistance index (DRI) have been used to determine the drought tolerance ability of plants (Fisher and Maurer, 1978; Bidinger et al., 1982). These indices were used to differentiate drought tolerance and drought susceptible cultivars (Dong and Liu, 2005). Drought resistance index has a positive or negative value. If this value is more than 1.3 then that the cultivar lies under the category of drought resistant and if this value is less than -1.3 then cultivar lies under the category of drought sensitive (Akcura et al., 2011). Song-ping et al. (2007) calculated the drought resistance index using the formula DRI $=$ Grain Yield under stress / Grain Yield under normal condition. When it was correlated with other parameters then it was found that this index was correlated with coleoptiles length of the recombinant inbreed line (RILs) of rice under moisture stress. Parameshwaarppa (2007) conducted a similar type of study and concluded that the genotypes which had least DSI value gave more yield, the highest drought tolerance efficiency and the highest drought tolerance index as compared to the other cultivars. They were also in argument that these cultivars maintained the highest harvest index under drought stress conditions.

\section{Conclusion}

It was concluded that injury and inoculation of apical meristem was found to be better before seed germination as compared to after seed germination. The transformation efficiency $(6.38 \%)$ was recorded based on PCR positive plants before germination. Under drought stress, germination percentage and germination rate index was higher in transgenic plants as compared to control plants. Proline contents were significantly increased which was a good indicator of drought tolerance. The stability of transgenic plants was higher as compared to control plant owing to more relative water contents, chlorophyll contents as well as length of shoots, roots and coleoptiles. The total improvement of transgenic plants in terms of drought tolerance efficiency (43.57\%) was higher in transgenic plants as compared to control plants.

Acknowledgements. This study was financially supported by Indigenous PhD Fellowship Program Higher Education Commission (HEC), Islamabad, Pakistan. The authors gratefully acknowledge the support of HEC for conducting $\mathrm{PhD}$ studies and the results presented here are part of $\mathrm{PhD}$ research of 
principal author. The authors acknowledge the support of National Institute for Genomics and Advanced Biotechnology (NIGAB), NARC, Islamabad, Pakistan for providing the facilities for the production of transgenic wheat. The authors also appreciate Plant Physiology Lab, PMAS, Arid Agriculture University, Rawalpindi, Pakistan for screening of drought tolerance in wheat transgenic line.

\section{REFERENCES}

[1] Abbas, R., Mirza, F. I., Afzal, A. (2017): Farm management capacities contribute to sustainability of rural livelihoods and income amongst small farmers in district Layyah, Punjab, Pakistan. - Journal of Rural Development and Agriculture 2: 11-25.

[2] Adeel, M., Siddiqui, B. N., Tareen, W. H., Rayit, A., Shah Fahd, S. (2017): Working efficiency of extension field staff with regard to integrated pest management of cotton in D. G. Khan, Punjab, Pakistan. - Journal of Rural Development and Agriculture 2: 26-40.

[3] Akcura, M., Partigoc, F., Kaya, Y. (2011): Evaluating of drought stress tolerance based on selection indices in Turkish bread wheat landraces. - Journal of Animal and Plant Sciences 21: 700-709.

[4] Alghabari, F., Ihsan, M. Z., Hussain, S., Aishia, G., Daur, I. (2015): Effect of Rht alleles on wheat grain yield and quality under high temperature and drought stress during booting and anthesis. - Environmental Science and Pollution Research 22: 15506-15515.

[5] Ali, N., Zada, A., Ali, M., Hussain, Z. (2016): Isolation and identification of Agrobacterium tumefaciens from the galls of peach tree. - Journal of Rural Development and Agriculture 1: 39-48.

[6] Ali, S., Kareem, K., Zia, M. A., Khan, S. U., Shahzad, A., Din, J. U., Ali, G. M. (2018): Expression analysis and introgression of transcriptional factor (DREB1A) in tomato for cold tolerance. - Journal of Pure and Applied Agriculture 3(1): 1-12.

[7] Ali, Z., Ashraf, M., Al-Qurainy, F., Khan, S., Akram, N. A. (2015): Appraising drought tolerance in local accessions of sesbania [Sesbania sesban (L.) Merril.] using biomass production, relative membrane permeability and photosynthetic capacity as selection criteria. - Pakistan Journal of Botany 47: 845-850.

[8] Amirjani, M. R., Mahdiyeh, M. (2013): Antioxidative and biochemical responses of wheat to drought stress. - APRN Journal of Agricultural and Biological Science 8: 292301.

[9] Amoah, B. K., Wu, H., Sparks, C., Jones, H. D. (2001): Factors influencing Agrobacterium tumefaciens mediated transient expression of uidA in wheat inflorescence tissue. - Journal of Experimental Botany 52: 1135-1142.

[10] Andrieu, A., Breitler, J. C., Sire, C., Meynard, D., Gantet, P., Guiderdoni, E. (2012): An in planta, Agrobacterium-mediated transient gene expression method for inducing gene silencing in rice (Oryza sativa L.) leaves. - Rice 5: 1-12.

[11] Anjum, A. S., Zada, R., Tareen, W. H. (2016): Organic farming: hope for the sustainable livelihoods of future generations in Pakistan. - Journal of Rural Development and Agriculture 1: 20-29.

[12] Anjum, S. A., Ashraf, U., Tanveer, M., Khan, I., Hussain, S., Shahzad, B., Zohaib, A., Abbas, F., Saleem, M. F., Ali, I., Wang, L. C. (2017): Drought induced changes in growth, osmolyte accumulation and antioxidant metabolism of three maize hybrids. Frontiers in Plant Science 8: 1-12. DOI: 10.3389/fpls.2017.00069.

[13] Arnon, D. I. (1949): Copper, enzyme in isolated chloroplasts polyphenoloxidase in Beta vulgaris. - Plant Physiology 24: 1-15.

[14] Ashraf, M., Foolad, M. R. (2007): Roles of glycine betaine and proline in improving plant abiotic stress resistance. - Environmental and Experimental Botany 59: 206-216.

[15] Bahar, B., Yildirim, M. (2010): Heat and drought resistances criteria in spring bread wheat: drought resistance parameters. - Scientific Research and Essays 5(13): 1742-1745. 
[16] Barrs, H. D., Weatherley, P. E. (1962): A re-examination of the relative turgidity technique for estimating water deficit in leaves. - Australian Journal of Biological Sciences 15: 413-428.

[17] Bates, L. S., Waldran, R. P., Teare, I. D. (1973): Rapid determination of free proline for water stress studies. - Plant and Soil 39: 205-208.

[18] Bayoumi, T. Y., Eid, M. H., Metwali, E. M. (2008): Application of physiological and biochemical indices as a screening technique for drought tolerance in wheat genotypes. African Journal of Biotechnology 7: 2341-2352.

[19] Bidinger, F. R., Mahalakshmi, Y., Talukdar, B. S., Alagarswamy, G. (1982): Improvement of Drought Resistance in Pearl Millet. - In: IRRI (ed.) Drought Resistance in Crops with Emphasis on Rice. - IRRI, Los Banos, Laguna Philippines, pp. 357-375.

[20] Bogale, A., Tesfaye, K., Geleto, T. (2011): Morphological and physiological attributes associated to drought tolerance of Ethiopian durum wheat genotypes under water deficit condition. - Journal of Biodiversity and Environmental Sciences 1: 22-36.

[21] Borisjuk, N., Kishchenko, O., Eliby, S., Schramm, C., Anderson, P., Jatayev, S., Kurishbayev, A., Shavrukov, Y. (2019): Genetic modification for wheat improvement: from transgenesis to genome editing. - BioMed Research International. https://doi.org/10.1155/2019/6216304.

[22] Bratic, A. M., Majic-Dragana, B., Miljus-Dukic, J. D., Jovanovic, Z. S., Maksimovic, V. R. (2007): In planta transformation in buckwheat (Fagopyrum esculentum Moench.). Archives of Biological Sciences 59: 135-138.

[23] Brunecky, R., Selig, M. J., Vinzant, T. B., Himmel, M. E., Lee, D., Blaylock, M. J., Decker, S. R. (2011): In planta expression of A. cellulolyticus Cel5A endocellulase reduces cell wall recalcitrance in tobacco and maize. - Biotechnology for Biofuels 4: 110.

[24] Camargo, C. P., Vaughan, C. E. (1973): Effect of seed vigor on field performance and yield of grain sorghum (Sorghum bicolor L.). - Proceedings of the Association of Official Seed Analytics 6: 135-147.

[25] Cheng, M., Fry, J. E., Pang, S., Zhou, H., Hironaka, C. M., Duncan, D. R., Conner, T. W., Wan, Y. (1997): Genetic transformation of wheat mediated by Agrobacterium tumefaciens. - Plant Physiology 115: 971-980.

[26] Cheng, M., Hu, T., Layton, J., Liu, C. N., Fry, J. (2003): Desiccation of plant tissues postAgrobacterium tumefaciens infection enhances T-DNA delivery and increases stable transformation efficiency in wheat. - In Vitro Cellular \& Developmental Biology - Plant 39: 595-604.

[27] Cushman, J. C., Bohnert, H. J. (2000): Genomic approach to plant stress tolerance. Current Opinion in Plant Biology 3: 117-124.

[28] Dong, B., Liu, M. (2005): Integrated evaluation to high yield and water saving of winter wheat in north China. - Agrifood Research Reports 68: 11-18.

[29] Errabii, T., Gandonou, C. B., Essalmani, H., Abrini, J., Idaomar, M., Skali-Senhaji, N. (2006): Growth, proline and ion accumulation in sugarcane callus cultures under droughtinduced osmotic stress and its subsequent relief. - African Journal of Biotechnology 5: 1488-1493.

[30] Fahliani, R. A., Assad, M. T. (2005): Evaluation of three physiological traits for selecting drought. - Journal of Agricultural Science and Technology 7: 81-87.

[31] Farooq, M., Aziz, T., Rehman, H. U., Rehman, A. U., Cheema, S. A. (2011): Evaluating surface drying and re-drying for wheat seed priming with polyamines: effects on emergence, early seedling growth and starch metabolism. - Acta Physiologiae Plantarum 33: 1707-1713.

[32] Filippou, P., Bouchagier, P., Skotti, E., Fotopoulos, V. (2014): Proline and reactive oxygen/nitrogen species metabolism is involved in the tolerant response of the invasive plant species Ailanthus altissima to drought and salinity. - Environmental and Experimental Botany 97: 1-10. 
[33] Fischer, K. S., Wood, G. (1981): Breeding and selection for drought tolerance in tropical maize. - Proc. Symp. on Principles and Methods in Crop Improvement for Drought Resistance with Emphasis on Rice, IRRI, Philippines.

[34] Fisher, R. A., Maurer, R. (1978): Drought resistance in spring wheat cultivars. I. grain yield response. - Australian Journal of Agricultural Research 29: 897-907.

[35] Hare, P. D., Cress, W. A., Staden, J. V. (1999): Proline synthesis and degradation: a model system for elucidating stress-related signal transduction. - Journal of Experimental Botany 50: 413-434.

[36] Hassan, U. A., Ogunlela, V. B., Sinha, T. D. (1987): Agronomic performance of wheat (Triticum aestivum L.) as influenced by moisture stress at various growth stages and seeding rate. - Journal of Agronomy and Crop Science 158: 172-180.

[37] He, Y., Jones, H. D., Chen, S. C., Chen, X. M., Wang, D. W., Li, K. X., Wang, D. S., Xia, L. Q. (2010): Agrobacterium tumefaciens-mediated transformation of durum wheat (Triticum turgidum L. var. durum, c.v. Stewart) with improved efficiency. - Journal of Experimental Botany 61: 1567-1581.

[38] Ishaq, W., Memon, S. Q. (2016): Roles of women in agriculture: a case study of rural Lahore, Pakistan. - Journal of Rural Development and Agriculture 1: 1-11.

[39] Jain, A. K., Basha, S. M., Holbrook, C. C. (2001): Identification of drought responsive transcripts in peanut (Arachis hypogaea L.). - Electronic Journal of Biotechnology 4: 1-9.

[40] Jan, S. A., Bibi, N., Shinwari, Z. K., Rabbani, M. A., Sana Ullah, Qadir, A., Khan, N. (2017): Impact of salt, drought, heat and frost stresses on morpho-biochemical and physiological properties of Brassica crops: an updated review. - Journal of Rural Development and Agriculture 2: 1-10.

[41] Jones, H. D. (2005): Wheat transformation: current technology and applications to gain development and composition. - Journal of Cereal Science 41: 137-147.

[42] Kasuga, M., Liu, Q., Miura, S., Yamaguchi-Shinozaki, K., Shinozaki, K. (1999): Improving plant drought, salt, and freezing tolerance by gene transfer of a single stressinducible transcription factor. - Nature Biotechnology 17: 287-291.

[43] Keyvan, S. (2010): The effects of drought stress on yield, relative water content, proline, soluble carbohydrates and chlorophyll of bread wheat cultivars. - Journal of Animal and Plant Sciences 8: 1051-1060.

[44] Khan, A. S., Allah, S. U., Sadique, S. (2010): Genetic variability and correlation among seedling traits of wheat (Triticum aestivum L.) under water stress. - International Journal of Agriculture and Biology 12: 247-250.

[45] Khan, S., Anwar, S., Yu, S., Sun, M., Yang, Z., Gao, Z. (2019): Development of droughttolerant transgenic wheat: achievements and limitations. - International Journal of Molecular Biology 20: 1-18. DOI: 10.3390/ijms20133350.

[46] Kumar, R. R., Karajol, K., Naik, G. R. (2011): Effect of polyethylene glycol induced water stress on physiological and biochemical responses in Pigeonpea (Cajanus cajan L. Millsp.). - Recent Research in Science and Technology 3: 148-152.

[47] Marcotte, W. R., Russel, S. H., Quatrano, R. S. (1989): Abscisic acid response sequences from $E m$ gene of wheat. - Plant Cell 1: 969-976.

[48] Mehmood, K., Arshad, M., Ali, G. M., Razzaq, A. (2013): Tissue culture responses of some wheat (Triticum aestivum L.) cultivars grown in Pakistan. - Pakistan Journal of Botany 45: 545-549.

[49] Mehmood, K., Arshad, M., Ali, S., Qayyum, M., Ali, G. M. (2016): Comparative study of tissue culture response of some selected basmati rice cultivars of Pakistan. - Journal of Rural Development and Agriculture 1: 30-38.

[50] Moaveni, P. (2011): Effect of water deficit stress on some physiological traits of wheat (Triticum aestivum). - Agricultural Science Research Journal 1: 64-68.

[51] Moussa, H. R., Abdel-Aziz, S. M. (2008): Comparative response of drought tolerant and drought sensitive maize genotypes to water stress. - Australian Journal of Crop Science 1: $31-36$. 
[52] Mowla, S. B., Thomson, J. A., Farrant, J. M., Mundree, S. G. (2002): A novel stressinducible antioxidant enzyme identified from the resurrection plant Xerophyta viscosa Baker. - Planta 215: 716-726.

[53] Mujtaba, S. M., Ali, M., Ashraf, M. Y., Khanzada, B., Farhan, S. M., Shirazi, M. U., Khan, M. A., Shereen, A., Mumtaz, S. (2007): Physiological responses of wheat (Triticum aestivum L.) genotypes under water stress conditions at seedling stage. Pakistan Journal of Botany 39: 2575-2579.

[54] Murray, M. G., Thomson, W. F. (1980: Rapid isolation of high molecular weight plant DNA. - Nucleic Acids Research 8: 4321-4325.

[55] Oh, S. J., Song, S. I., Kim, Y. S., Jang, H. J., Kim, S. Y., Kim, M., Kim, Y. K., Nahm, B. H., Kim, J. K. (2005): Arabidopsis CBF3/DREB1A and ABF3 in Transgenic Rice Increased Tolerance to Abiotic Stress without Stunting Growth. - Plant Physiology 138: 341-351.

[56] Parameshwarappa, S. G., Salimath, P. M. (2007): Field screening of chickpea genotypes for drought resistance. - Karnataka Journal of Agricultural Sciences 21: 113-114.

[57] Pellegrineschi, A., Reynolds, M., Pacheco, M., Brito, R. M., Almeraya, R., Shinozaki, K. Y., Hoisington, D. (2004): Stress-induced expression in wheat of the Arabidopsis thaliana DREB1A gene delays water stress symptoms under greenhouse condition. Genome 47: 493-500.

[58] Prasad, P. V. V., Pisipati, S. R., Momcilovic, I., Ristic, Z. (2011): Independent and combined effects of high temperature and drought stress during grain filling on plant yield and chloroplast EF-Tu expression in spring wheat. - Journal of Agronomy and Crop Science 197: 430-441.

[59] Qayyum, A., Razzaq, A., Ahmad, M., Jenks, M. A. (2011): Water stress causes differential effects on germination indices, total soluble sugar and proline content in wheat (Triticum aestivum L.) genotypes. - African Journal of Biotechnology 10: 1403814045.

[60] Rab, M. A., Sultan, F., Hui, L., Yang, L. J., Xian, Z. H. (2012): Assessment of drought tolerance of some Triticum Species through physiological indices. - Czech Journal of Genetics and Plant Breeding 48: 178-184.

[61] Rao, K. S., Sreevathsa, R., Pinakee, D., Sharma, D., Keshamma, E., Kumar, M. U. (2008): In planta transformation of pigeon pea: a method to overcome recalcitrancy of the crop to regeneration in vitro. - Physiology and Molecular Biology of Plants 14: 321-328.

[62] Raziuddin, Swati, Z. A., Bakht, J., Farhatullah, Ullah, N., Shafi, M., Akmal, M., Hassan, G. (2010): In situ assessment of morpho-physiological response of wheat (Triticum aestivum L.) genotypes to drought. - Pakistan Journal of Botany 42: 3183-3195.

[63] Razzaq, A., Yan-min, Z., Fan, Y., Yan-Jie, Y., He, Z., Zhi-ying, M., Hai-bo, W. (2005): In planta transformation of wheat apical meristem: a preliminary study. - Acta Agriculturae Boreali Sinica 20: 17-22.

[64] Ritchie, S. W., Nguyan, H. T., Holaday, A. S. (1990): Leaf water content and gas exchange parameters of two wheat genotypes differing in drought resistance. - Crop Science 30: 105-111.

[65] Rong-Hua, L. I., Pei-Guo, G., Baum, M., Grando, S., Ceccarelli, S. (2006): Evaluation of chlorophyll content and fluorescence parameters as indicators of drought tolerance in barley. - Agricultural Sciences in China 5: 751-757.

[66] Saidi, A., Ookawa, T., Motobayashi, T., Hirasawa, T. (2008): Effects of soil moisture conditions before heading on growth of wheat plants under drought conditions in the ripening stage: insufficient soil moisture conditions before heading render wheat plants more resistant to drought during ripening. - Plant Production Science 11: 403-414.

[67] Seki, M., Narusaka, M., Abe, H., Kasuga, M., Yamaguchi-Shinozaki, K., Carninci, P., Hayashizaki, Y., Shinozaki, K. (2001): Monitoring the expression pattern of 1300 Arabidopsis genes under drought and cold stresses by using a full-length cDNA microarray. - Plant Cell 13: 61-72. 
[68] Shah, S. H., Ali, S., Jan, S. A., Din, J., Ali, G. M. (2015): Piercing and incubation method of in planta transformation producing stable transgenic plants by overexpressing DREBIA gene in tomato (Solanum lycopersicum Mill.). - Plant Cell, Tissue and Organ Culture 120: 1139-1157.

[69] Sieling, K., Christen, O., Richter-Harder, H., Hanus, H. (1994): Effects of temporary water stress after anthesis on grain yield and yield components in different tiller categories of two spring wheat varieties. - Journal of Agronomy and Crop Science 173: $32-40$.

[70] Song-Ping, H., Hua, Y., Gui-Hua, Z., Hong-Yan, L., Guo-Lan, L., Han-Wei, M., Run, C., Ming-Shou, L., Li-Jun, L. (2007): Relationship between coleoptile length and drought resistance and their QTL mapping in rice. - Rice Science 14: 13-20.

[71] Stoyanov, Z. (2005): Effects of water stress on leaf water relations of young bean plants. - Journal of Central European Agriculture 6: 5-14.

[72] Strange, K., Yancey, P. H. (1994): Compatible and Counteracting Solutes. -In: Strange, K. (ed.) Cellular and Molecular Physiology of Cell Volume Regulation. CRC Press, Boca Raton, FL, pp. 81-109.

[73] Valifard, M., Moradshahi, A., Kholdebarin, B. (2012): Biochemical and physiological responses of two wheat (Triticum aestivum L.) cultivars to drought stress applied at seedling stage. - Journal of Agricultural Science and Technology 14: 1567-1578.

[74] Wu, H., Sparks, C., Amoah, B., Jones, H. D. (2003): Factors influencing successful Agrobacterium tumefaciens-mediated genetic transformation of wheat. - Plant Cell Reports 21: 659-668.

[75] Xue, Q., Zhu, Z., Musick, J. T., Stewart, B. A., Dusek, D. A. (2003): Root growth and water uptake in winter wheat under deficit irrigation. - Plant and Soil 257: 151-161.

[76] Yao, Q., Cong, L., Chang, J. L., Li, K. X., Yang, G. X., He, G. Y. (2006): Low copy number gene transfer and stable expression in a commercial wheat cultivar via particle bombardment. - Journal of Experimental Botany 57: 3737-3746.

[77] Yenchon, S., Te-chato, S. (2012): Effect of bacteria density, inoculation and cocultivation period on Agrobacterium tumefaciens mediated transformation of oil palm embryogenic callus. - Journal of Agricultural Technology 8: 1485-1496.

[78] Yin, Z., Plder, W., Malepszy, S. (2004): Transgene inheritance in plants. - Journal of Applied Genetics 45: 127-144.

[79] Zhang, J. Y., Broeckling, C. D., Blancaflor, E. B., Sledge, M. K., Sumner, L. W., Wang, Z. Y. (2005): Over expression of WXP1, A putative Medicago truncatula AP2 domaincontaining transcription factor gene, increases cuticular wax accumulation and enhances drought tolerance in transgenic alfalfa (Medicago sativa). - Plant Journal 42: 689-695.

[80] Zhu, J. K. (2001): Plant salt tolerance. - Trends in Plant Science 6: 66-71. 